\title{
THE VIRGIN MARY (PANAGIA/ THEOTOKOS) IN MODERN GREEK INCANTATIONS: THE SACRED AFFLICTED
}

\section{Haralampos Passalis}

A guest lecturer at the University of Amsterdam and at the Greek School "Athena", Amsterdam, Netherland

harapass168@gmail.com

\begin{abstract}
Sacred personae of the officially recognized religious systems often appear in charms in order to enhance the therapeutic efficacy of the ritual. Their appearance is particularly common in Greek narrative charms where they often assume the role of the auxiliary agent who expels the malevolent factor and provides a cure to the afflicted person. In this context, the appearance of Christ, the Virgin Mary, Angels, Archangels, the Apostles, as well as various saints, is also quite frequent. There is, however, a peculiarity in terms of the role that the figure of the Virgin Mary (Panagia, Theotokos) assumes. This holy figure can not only assume the role of an auxiliary sacred agent who provides a cure to the afflicted person, but also the role of the afflicted, seeking healing treatment by another holy figure. Worth mentioning in the last case is that this affliction could have as its source another sacred figure such as the Apostles or even the Angels. In which particular charm-types does the Virgin Mary appear as the afflicted person? Which are the factors leading to the onset of this affliction and which are the symptoms experienced by the holy figure? How is this affliction cured and by whom? How could we, finally, explain this ambiguity of the Virgin Mary (Panagia) who appears to be standing in a liminal and transitional space between the sacred and the secular, divine and human, healer and afflicted? These are some of the questions that this article seeks to examine and answer.
\end{abstract}


Keywords: Virgin Mary, Greek narrative charms, evil eye, afflicted sacred figures, Greek folk religion, Apostles, Angels, liminality/ambiguity

\section{INTRODUCTION}

The Lady of the Angels and the Joy of the Archangels divine cloth she wore and sat on a throne [....$^{1}$ The sacred figure cited as "The Lady of the Angels and the Joy of the Archangels" in the above excerpt of an charm against the evil eye can be easily identified with the Virgin Mary (Greek П $\alpha v \alpha \gamma i$ í [Panagia]). Such an association is not coincidental. The connection of the Virgin Mary with angelic realms and her superiority in sacred hierarchy is often illustrated in Byzantine icons and in the official ecclesiastic orthodox hymnology. ${ }^{2}$ Hence, unsurprisingly we often find references in charms, such as the following:

The Virgin Mary $[\ldots]$ worshipped by the Archangels $[\ldots] .^{3}$

The Virgin Mary sat with thousands of Angels, with countless Archangels $[\ldots]$. $^{4}$

The Lady Virgin Mary arrived at the Mount of Olives surrounded by the wings of thousands of angels and archangels $[\ldots] .^{5}$

Far, farther away from the Jordan River there walked the Virgin Mary, my Lady, with four hundred angels $[\ldots] .^{6}$

The worship of the Virgin Mary is so widespread in Modern Greek traditional culture that exceeds that of any other sacred figure. There is a surprisingly large number of churches and monasteries dedicated to her grace in all parts of

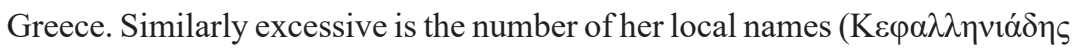

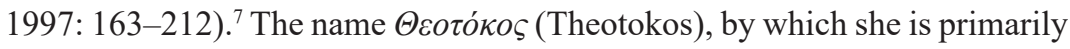
mentioned in the literary ecclesiastic tradition of the eastern Christianity, denotes the woman who gave birth to God himself. In Greek traditional culture,

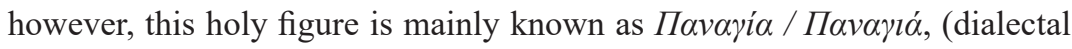

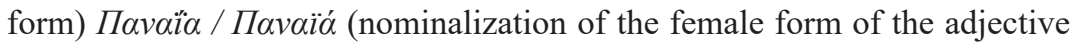

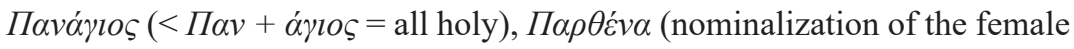
form of the adjective $\Pi \alpha \rho \theta \varepsilon \dot{\varepsilon} \sigma \varsigma$, virgin) in addition to honorary titles $\Delta \varepsilon \dot{\varepsilon} \sigma \pi o l v \alpha$

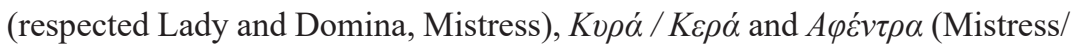
Lady). ${ }^{8}$ 
This sacred figure is repeatedly encountered in charms, since in the folk religious system of the Greek traditional culture she is considered to bear the energy of the sacred par excellence. Her name is frequently an essential supplement in the catalogues of holy figures. ${ }^{9}$ Such a reference is typically and fundamentally closely associated with the performer of the ritual who, in this way, attracts the energy of the sacred, hence enhancing the effectiveness of the treatment. Indicative of the considered sacred power of the Virgin Mary is the

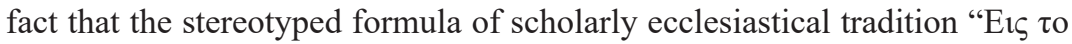

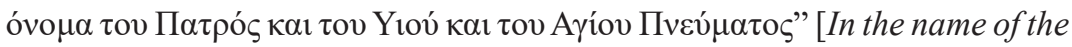
Father and the Son and the Holy Spirit] is altered in oral tradition to "Eıऽ $\tau$

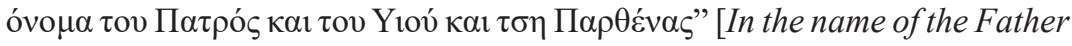

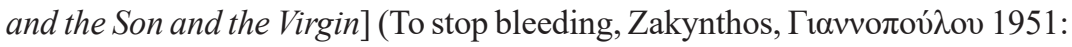
267). ${ }^{10}$ This has not happened by chance, since the Virgin Mary is, as cited

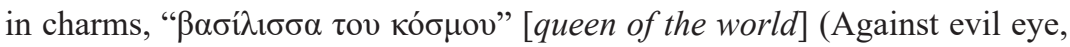

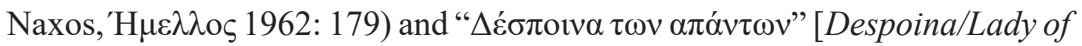

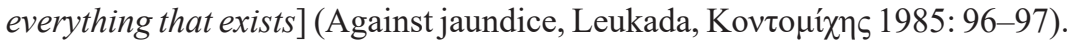

\section{THE VIRGIN MARY IN GREEK NARRATIVE INCANTATI- ONS}

Elements for the identity of this sacred figure, as developed in the frame of the folk religious system, are traced in Modern Greek narrative charms, in which Паvayia takes on one of the main principal roles. The most representative case of her ultimate sacred power is recorded in charms based on the typical structural model of the encounter of a sacred power with the personified cause of the evil. In this type, the Virgin Mary appears as the leading sacred figure which encounters and exorcises the malevolent agents. A typical example of such a case is the following:

The Lady Theotokos and the Mistress of all that exists met Hector, yet she did not salute him, only stood and told him: -Where are you heading to, Nectora, Dictora (=nonsensical words whose formation is based on

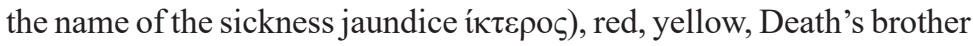
and Lord, along with Death, of death? He [The Jaundice] replied and said to Mother of God: -The Earth saw me and was appalled. The rocks saw me and got torn apart and you ask where I am heading to? - I go to this God's servant to burn his kidneys. Then, Theotokos exorcised 
him holding a golden ring by saying: -Go to Tartaro (=the river of the underworld) itself, because this servant of God is baptized in the name of the Father and the Holy Spirit. ${ }^{11}$

An independent and autonomous benevolent interference often appears in narrative charms based on the structural model in which an assistant sacred figure meets with the sufferer himself. ${ }^{12}$ In those charms the Virgin Mary herself encounters the sufferer and heals him providing the necessary therapeutic instructions:

[...] The Virgin Mary came [and said to the afflicted person:]. -What is wrong and you are in pain and you are crying? [The afflicted person answered:] -Red (name of the disease) caught me. [The Virgin Mary said:] -Set a fire, find seven pieces of thick cloth, cut them in seven parts, place them inside out and burn them. ${ }^{13}$

The power and her supremacy are also apparent in charms where the charmer appears in the narrative using only her name in order to command the malevolent agents to disappear:

$[\ldots]$ Panagia, the Mistress told me $[\ldots]$ to say $[\ldots]^{14}$

It seems as if the independent therapeutic intervention diminishes when the Virgin Mary appears as a member of a group of sacred figures, as in the following case:

Forty brothers up on the mountain chopped wood for ceilings and floors and windows. And there drops an axe off one's hands and hits him on [that part of his body]. And John the Baptist and the Virgin Mary, the Mistress, told him to take the wool from a black sheep, to enchant and heal it $[\ldots] .^{15}$

It has to be noted that such instances are not associated with decreasing the authority of the sacred figure summoned by the healer, but with the rhetorical strategy applied in charms to enhance and establish the healing outcome by pleading as many sacred figures as possible. ${ }^{16}$

The Virgin Mary's autonomy is weakened when she undertakes the role of a mediator between the sufferer and the sacred power, which she herself pleads to help solve the problem. In an incantation from the area of Paros used 
to heal jaundice, after meeting with the evil factor, the Virgin Mary pleads God to help her cure the disease. God promptly responds to her summon and sends St. George:

[...] The Virgin Mary made with her hands the sign/gesture of the cross and pleads upon God. The God quickly sends [...] St. George who is riding his horse holding a lance $[\ldots] \cdot{ }^{17}$

The power of the Virgin Mary to intervene and handle crucial situations seems to be diminished or even to be annulled in the charms she undertakes the role of the victim. In those instances, the Virgin Mary appears to be afflicted by a disease and gets sick. It is surprising that a sacred figure, especially that of the Virgin Mary, who in other instances has the power to heal and exterminate evil, becomes its victim and in some cases is infected by the same diseases that she heals. ${ }^{18}$ Finally, it is worth considering that "the Lady of the Angels and joy of the Archangels" can be afflicted by the very same sacred escorts like the Angels and the Apostles. All these issues will be addressed below.

\section{THE TYPE “THE VIRGIN MARY AFFLICTED”}

The narrative charms in which the Virgin Mary is presented as afflicted are widespread in many areas of Greece, more widely in Cyprus (I $\omega$ vós 2007B:

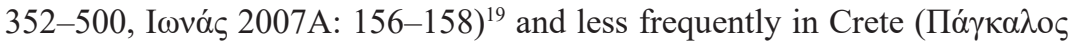

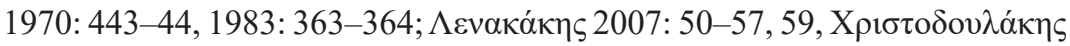

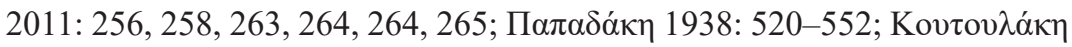

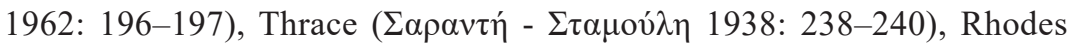

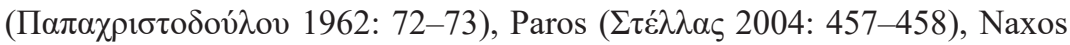

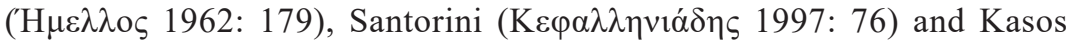

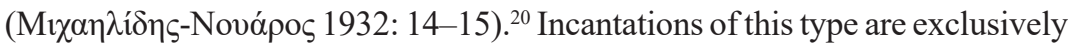
used against the evil eye. ${ }^{21}$ In Ionas' compilation (I $\omega v \alpha$ ć 2007) of Cypriot incantations, 140 samples of this type have been documented, allowing us to refer to it as a widespread, unique type of charms with specific structural traits. ${ }^{22}$ They include an extensive text which, along with stereotyped introductory and concluding frames, can be up to 65 verses in length. In Cyprus they are known

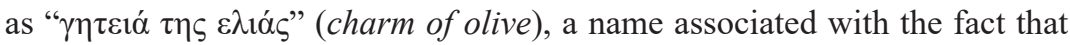
the recitation of the narrative is always accompanied by smoking olive leaves

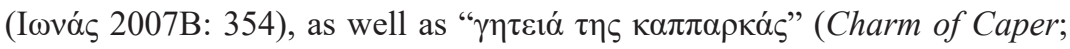


Caper spinosa kapparka, a native herb to which the transfer of the evil eye is attempted). It is worth mentioning that this type of charms is exclusively recorded in oral tradition, since the exact literary source in the written tradition of charms - if it exists at all — cannot be traced.

The structure of those charms consists of two characteristic parts. The first part includes a stereotyped introduction, where the Virgin Mary is presented taking care of her physical appearance, embellishing herself and carrying out various domestic chores or other tasks. Her impressive image provokes admiration by various encounters who consequently cast the evil eye on her. What follows is an analytical description of milder or more serious physical symptoms caused by the affliction. Then, the Virgin Mary meets the sacred figure (healer) exchanging stereotyped answers and questions. These dialogues involve the sacred figure's inquiry of the cause of the evil eye and the Virgin Mary's response, which is based on the repetition of the entire typical introduction as she explains the reason for her symptoms. This section apart from the expected trivial variations is common in almost all charms of this type.

Nonetheless, significant variations are evident in the second part with reference to the therapeutic treatment. Despite the amalgamation of various types of charms, additions, abstractions and omissions of parts due to the oral transmission, we can distinguish three different versions of therapeutic intervention (see the Appendix for representative example of each type). The first version (see Appendix, type 1) involves standardized instructions to perform specific rituals (actions and/or words). The second (see Appendix, type 2) follows the characteristic pattern of a wide category of Greek narrative charms, based on the meeting of the personified cause of evil with the sacred figure

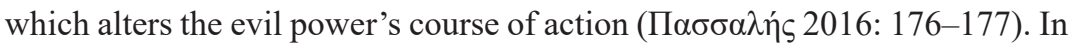
the third version (see Appendix type 3) healing intervention is based on the transfer of the evil eye to organic or/and inorganic substances with the view to annul its influence. Detailed analysis of these three versions will follow in a section of this article referring to the therapeutic treatment.

\section{THE CONTEXT OF AFFLICTION}

The first section of these charms starts with the characteristic introduction in which the main character is the Virgin Mary, who performs a series of activities purely connected to her human/secular dimension. Those activities are related to taking care of her body and generally her physical appearance. 
Often after completing all these activities, the Virgin Mary sits on her throne usually dressed in her sacred vestment:

The Virgin Mary, the Mistress, washed and combed her hair, wore her (sacred) vestment, sat on her throne $\left[\ldots . .{ }^{23}\right.$

The Virgin Mary, the Mistress, washed and combed her hair, sat on her golden throne $[\ldots] .{ }^{24}$

In other instances the Virgin Mary after her usual embellishment and sitting on her throne deals with textile activities:

The Virgin Mary, the Mistress, has woken up since dawn, washed and combed her hair, put on a headscarf and had made with her hands the sign of the cross, took a golden spin, turned a golden wheel, filled seven wheels $[\ldots] .^{25}$

The Virgin Mary, the Mistress, sat on her throne. She arrowed seven little threads and she filled seven spindles $[\ldots] .{ }^{26}$

Quite frequent is the reference to Virgin Mary's involvement with household, like doing the laundry and sweeping:

$[\ldots]$ She washed and rinsed, and she laid the clothes over laurel $[\ldots] .{ }^{27}$

The Virgin Mary, the Lady, woke at dawn swept and sprinkled water $[\ldots] .{ }^{28}$

The list of activities is more rarely enriched with charities like building of churches, ordination of priests and endowment of orphans (Cyprus,

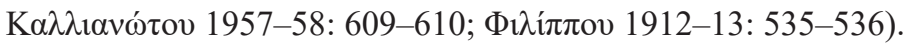

The time of the incident is usually undefined. Saturday is mentioned in some cases (Crete, П $\alpha \pi \alpha \delta \alpha ́ \kappa \eta ~ 1938: 520-521)$, whereas Thursday is cited in

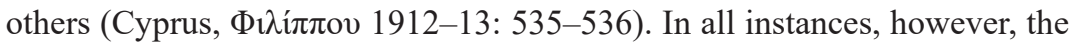
defined time when specific activities occur is the morning, at the crack of dawn:

The Virgin Mary, the Lady, she wakes at dawn [...]. ${ }^{29}$

$[\ldots]$ at dawn $[\ldots]$ and the sun $\operatorname{did}$ not rise $[\ldots] .{ }^{30}$ 
The place is usually undefined. It is probably the area where the Virgin Mary lives, which is inferred by the kind of activities she performs. In some cases there is a reference to the cave of Christ's birth: ${ }^{31}$

\section{$[\ldots]$ into horses' barn $[\ldots] .{ }^{32}$}

The Virgin Mary gave birth into a Cave and bore Jesus Christ. In eight days she washed her hair and sat on her throne $[\ldots]^{33}$

\section{THE AGENTS OF AFFLICTION}

The Virgin Mary's appearance provokes the admiration and the envy of passersby who usually happen to be going past the area where they encounter her. Those individuals belong to two different categories of figures. The first category of those who cast the evil eye on the Virgin Mary includes women with strange, disfigured external characteristics and malformations: " $\eta \delta \eta \sigma o \beta \rho v o v$,

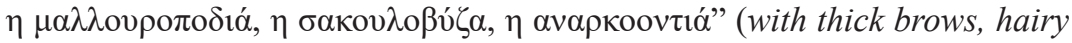

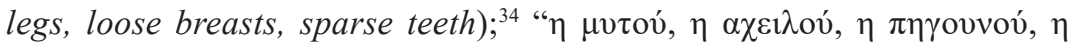

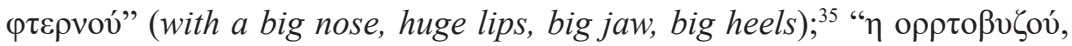

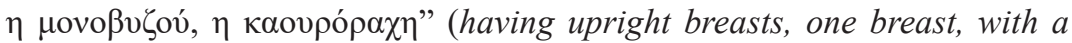

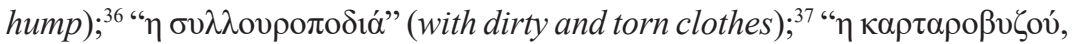

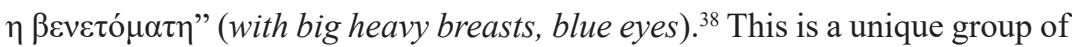

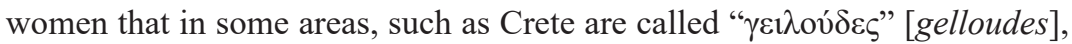
a name derived from the female demon $\Gamma \varepsilon \lambda \lambda$ ov́ [Gellou], whose main target

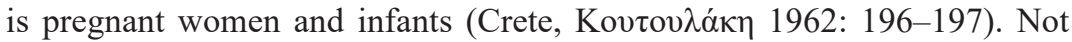
surprisingly, the name of $\Lambda \alpha \dot{\mu} \alpha$ (Lamia, a female demonic figure of Greek folk tradition who lethally attacks babies) appears in the list of those women

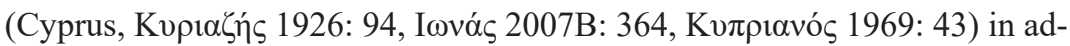

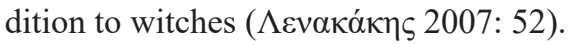

The second category of those who cast the evil eye includes a group of sacred figures like the Apostles:

[...] Twelve Apostles passed by and admired her [...]. ${ }^{39}$

$[\ldots]$ The Apostles saw and admired her $[\ldots]^{40}$

[...] Twelve Apostles passed by and saw her and cast an evil eye on her $[\ldots]{ }^{41}$ 
Angels are also incorporated in the catalogue of the holy figures who cast the evil eye on the Virgin Mary:

$[\ldots]$ and the angels passed and casted the evil eye on her $[\ldots]^{42}$

$[\ldots]$ The angels passed and cast their evil eye on her $[\ldots]{ }^{43}$

In some instances the angels and the apostles constitute one group:

The Virgin Mary gave birth and washed and combed her hair and wore her angelic vestment, her golden apostolic clothes and started walking. Saints Angels encountered her on the road and the twelve Apostles and saw her, lusted after her and put the evil eye on her $[\ldots]{ }^{44}$

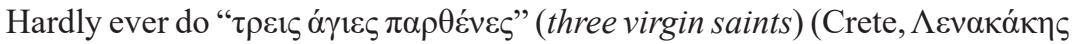

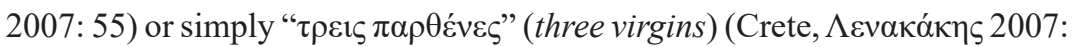

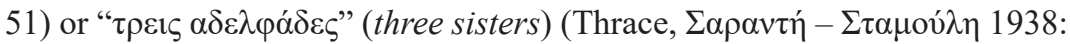
238-240) appear.

\section{SYMPTOMS AND PATHOLOGY}

What is the evil eye's pathology? That is to say, what are the symptoms which signify and verify the casting of the evil eye, thus revealing the Virgin Mary's human dimension? Headache and fever are incorporated in the main pathology leading to her resigning from her activities:

$[\ldots]$ her head sharply ached, she shivered and her thread was cut $[\ldots]{ }^{45}$ In other instances, fever forces the Virgin Mary to lie down:

[...] In black chill the Virgin Mary shivered and lay and pondered and covered up $[\ldots]^{46}$

[...] she lay and covered up, shivered in fever but found no comfort and called her son, the only begotten Son $[\ldots]{ }^{47}$

The list of symptoms extends further to include not only intense headache, sore throat, abdominal pain, lower back pain but also pain in joints and bones:

[...] she suffered from headache, sore throat and abdominal pain and covered up with her sheet $[\ldots] .{ }^{48}$ 
$[\ldots]$ hear head ached and she lay and covered up $[\ldots]{ }^{49}$

$[\ldots]$ headache, pain in the eye and toothache $[\ldots]^{50}$

[...] headache, sore throat, abdominal pain, lower back pain, pain in bones $[\ldots] .^{51}$

What is also included in the intense symptoms is paleness of the face and the loss of the Virgin Mary's hair:

$[\ldots]$ The colour of red roses on her face faded away, her hair fell $[\ldots] .{ }^{52}$

The evil eye's pathology is also evident in Christ's words when he encounters with his mother:

[...] -Mother, what is wrong, and you curled up and bandaged your head and leaned against your throne? $[\ldots]^{53}$

[...] Christ passed by and saw her pale her expression was fatigued $[\ldots] .^{54}$

The intensity of symptoms is illustrated in some cases through excessive/ dramatic utterances like:

$[\ldots]$ She sighs and that sigh was heard on heaven $[\ldots]^{55}$

[...] The Virgin Mary, the Mistress, sobs and mourns, she withers trees and she dries up rivers $[\ldots] .{ }^{56}$

The Virgin Mary's human dimension is also realized through her expression of fear due to her encounter with those women with the distorted external characteristics:

[...] The Virgin Mary, my Mistress was terrified and pulled her gold sheet, placed it over her head [...] and cried: Run, Angels-Archangels, to stop evil with your hand $[\ldots] .{ }^{57}$

\section{THE THERAPIST AND THE THERAPY}

No other sacred authority could better undertake the role of healer than Christ himself, who in most cases constitutes the main benevolent agent dealing ef- 
ficiently and effectively with the affliction of the Virgin Mary. ${ }^{58}$ The therapeutic intervention of this sacred figure emerges in three different forms. The first type includes instructions delivered by Christ to the Virgin Mary to perform a combination of verbal and non-verbal rituals, usually the smoking of olive leaves (hence the name "charm of the olive", I $\omega v \alpha$ ć 2007B: 354-388) accompanied

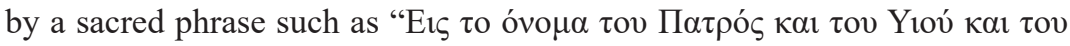

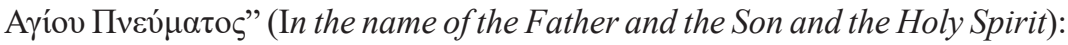

[...] Take three olive leaves and say: In the name of the Father and the Son and the Holy Spirit. ${ }^{59}$

[...] Didn't you have, my mother, three olive leaves to say in the name of the Father and the Son and the Holy Spirit. ${ }^{60}$

In other instances, the therapeutic instructions involve simply the reciting a sacred formula which is simply based on the repetition of the Lord's Prayer or the sacred name of Christ (Kúpıs):

[...] Wasn't there any person with five fingers to say Our Father nine times? Our Father one, Our Father two, Our Father three, [...] Our Father nine. ${ }^{61}$

[...] Say, my mother, Kyrios one, Kyrios two [...] Kyrios nine, three times. $^{62}$

While the first type appears irrespective of the category the agents who provoke the affliction belong to, the second and the third type of therapeutic approach are only evident in cases where the evil eye is cast by non-sacred figures. Obviously, the casting of the evil eye by a non-sacred figure is considered to be more powerful, thus demanding a more drastic intervention of the healer. In the second equally widespread type of therapeutic intervention the text follows the structure of charms based upon the encounter of a sacred figure with the wicked power which is in process of causing harm (Cyprus, I $\omega v$ ós 2007B: 404, 405-406, 408, 409, 410-411, 417-418, 421-422, 428, 430, 436-486, 488, 500 ). In these cases, what is added in the first part of the stereotypical dialogue between Christ and the Virgin Mary is Christ's question about the direction of those powers as well as the Virgin Mary's response: 
[...] Where did they go, my mother; -They go to the east $[\ldots]{ }^{63}$ [...] -Where did she head for? -She headed towards west $[\ldots]{ }^{64}$ [...] -And where are they going now? -They go out in the villages to wither trees and bury the young and small children in the ground $[\ldots]{ }^{65}$ [...] -And where did she go, my mother; -In the underworld, deep in earth $[\ldots] .{ }^{66}$

What follows is those malevolent agents' pursuit by Christ, their encounter and a stereotypical dialogue between the sacred figure and the malevolent agents in relation to the course of their actions:

[...] There goes Christ and catches them and says to them: -Where are you heading for, you, the one with the black eyes, with hair on your legs and hanging breasts? -We go to dry trees out and bury the young and small children $[\ldots] .{ }^{67}$

The therapeutic strategy applied is based on altering their direction. The location to which Christ diverts the malevolent agent is a sacred place, usually the

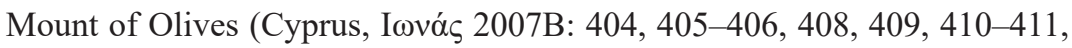
417-418, 421-422, 428, 430), where, in most cases, a marble pond is set (I $\omega v a ́ s$

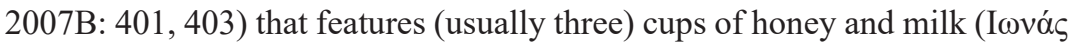
2007B: 396). Christ commands the malevolent agents to eat the honey, drink the milk and leave there all their negative influence:

$[\ldots]$ Go up the mount of Olives, eat and release your anger $[\ldots]{ }^{68}$

[...] Eat the honey, drink the milk, drop your bitterness and come back $[\ldots] \cdot{ }^{69}$

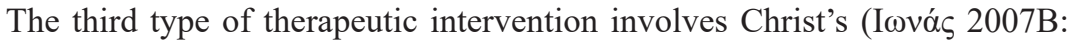

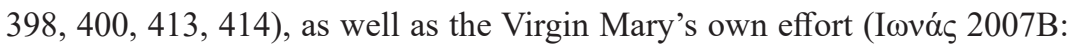
$383-386,390)$ to transfer the negative influences into various places in order to annul and stop their effect:

[...] The Virgin Mary got the evil eye with her right hand and dragged her [the malevolent agent] to the mountain to get lost and cut into pieces. 
The mountain growled and shouted: 'Oh, my dear Virgin Mary, my Mistress, I can bear thousands of people yet, I cannot stand envy and the evil eye'. The Virgin Mary, my dear Mistress, took it, and sank it into the sea to drown and disappear. There were waves at the seashore and ships and boats sank. [The sea said:] 'My dear Virgin Mary, my Mistress, I can bear thousands of people yet, I cannot stand envy and the evil eye'. My dear Virgin Mary, my Mistress, took him, and dragged it to caper whose root is on the rock and its leaves forever bitter. ${ }^{70}$

After numerous attempts, the sacred figure ends up transferring the negative influence into a plant ( $\kappa) \alpha \pi \pi \alpha \rho \kappa \alpha$, the well-known thorny plant of caper

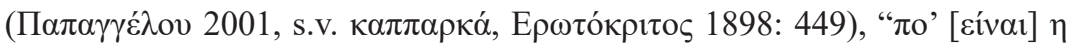

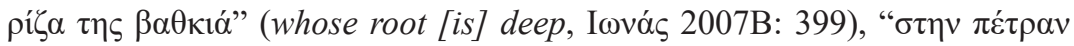

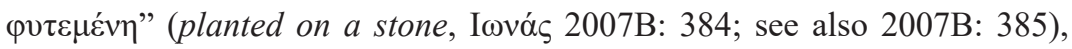

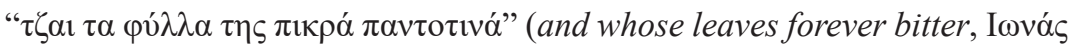
2007B: 383). The vast number of the charms of this type resulted in their being referred to by collectors as the "charm of caper" (Cyprus, I $\omega v$ ó $2007 \mathrm{~B}$ : 383-386, 390, 398, 400, 413, 414).

Much fewer in number are the instances where the therapeutic intervention is performed by an angel or a group of angels following the Virgin Mary's direct plea to the angels or to Christ:

[...] and called her begotten Son and the Lord's Angel came and told her: -What is wrong, my Lady, and you cry and you sigh and call God's name? [...] And the Angel told his Lady: -Take three olive leaves in your hand and form the sign of the cross in the name of the Father and the Son and the Holy Spirit now and forever. Amen $[\ldots]^{71}$

[...] The Virgin Mary, my Lady, is scared [...] and cried: Run, AngelsArchangels, and stop evil with your hand $[\ldots] .^{72}$

\section{EVIL EYE AND THE VIRGIN MARY}

All the incantations in which the Virgin Mary is presented as afflicted are used against the evil eye, a widespread affliction which has diverse and severe symptoms. ${ }^{73}$ Its source is to be traced in the admiration/fascination (cf. Latin fascino and Greek $\beta \alpha \sigma \kappa \alpha i v \omega)$, as well as the subsequent envy evoked either 
consciously or unconsciously by sight of a person, animal, or even object. As previously observed, in almost every stereotyped introduction of this type of charms, the Virgin Mary's physical appearance and activities are emphasized constituting her ex principio a potential victim of the forthcoming affliction. ${ }^{74}$ Therefore it is not surprising that in some charms against the evil eye the list of women encountering the Virgin Mary includes the personified $\zeta \eta \dot{\lambda} \lambda \alpha$ (=jealousy,

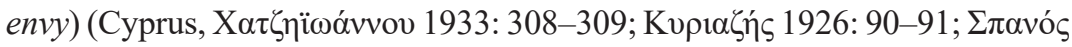

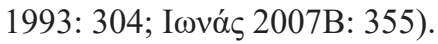

Biologically sensitive groups like parturient women, new mothers and small children are potential victims susceptible to the evil eye. ${ }^{75}$ The Virgin Mary represents the prototype of a great mother who gave birth to God himself. ${ }^{76}$ Thus, in some charms, the enchantment is as expected, located in the cave

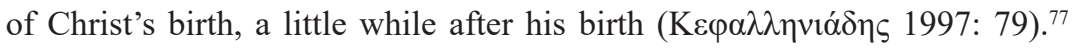
Likewise, quite expectedly, the outcome of the enchantment is the ceasing of the Virgin Mary's milk:

$[\ldots]$ She neither eats nor drinks nor her begotten son breastfeeds $[\ldots]{ }^{78}$

The association of the Virgin Mary with motherhood explains also why in some charms the list of figures that cast the evil eye includes women called

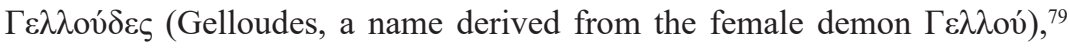
whose enchantment is directed against everyone, yet is mostly aimed at biologically and socially vulnerable groups, like pregnant women, but primarily against small children. ${ }^{80}$

An additional indication that relates and explains the effect of the evil eye on a sacred figure is the fact that the enchantment does not originate from any deliberate, conscious ill intention of those people to harm, but it is due to an uncontrolled inner power (cf. uncontrolled power, Douglas 1966: 98-99; witchcraft, Evans-Pritchard 1977: 10, 21$)^{81}$ that some taboo categories intrinsically have. ${ }^{82}$ Quite characteristic is the expression that often appears in charms of this type and refers to the lack of ill intention of the people to cause harm:

$[\ldots]$ they told her good words but harm was caused $[\ldots] .^{83}$

$[\ldots]$ she was told something good and evil returned to her $[\ldots]{ }^{84}$

$[\ldots]$ she was told good words and bad things happened $[\ldots]{ }^{85}$ 
Admiration in combination with the lack of intention to cause harm as a source of affliction allow for the appearance of sacred figures in place of those who cast the evil eye, like the Apostles and Angels, who are part of the Virgin Mary's escort. Nonetheless, when suffering derives from sacred figures, a certain differentiation is noticed not only in the intensity of the symptoms but also in their treatment. In these cases, the method of treatment is based on a mild, simple therapeutic procedure, including the reciting of a simple prayer and smoking of leaves from the holy olive tree.

\section{THE LIMINALITY AND AMBIGUITY OF PANAGIA}

Within the frame of both the folk and the official religious system, the figure of the Virgin Mary is a symbolic representation of a liminal space between different categories. ${ }^{86}$ The basic quality of such a liminal space lies in the fact that it represents a blurring of the distinction between divine and human, spiritual and secular, and while it belongs to both categories, it falls in neither one. ${ }^{87}$ This role has been credited to her, as she constitutes the superior expression of a human existence that is able to stand in this liminal sacred space and fulfill the incarnation of God himself. This liminal space constitutes a "locus of power" allowing for the undertaking of roles from both categories: as a divine figure who heals or facilitates treatment and as a suffering human seeking for the divine agent's contribution to heal.

The efficacy of the mediation is enhanced by the fact that she is the mother of the God himself. ${ }^{88}$ The display and exposure of this mother-son relationship is a particularly powerful element of the rhetoric of such charms. Christ, as son of the Virgin Mary and God himself who can effectively facilitate a problem's resolution, addresses to the Virgin Mary which is his mother and, at the same time, a superior figure of the sacred hierarchy:

And Christ asks her. - What is wrong, my dear mother, what is wrong, my Virgin, what is wrong, Lady of the world? [... ${ }^{89}$

[...] Her son heard her. -What is the matter, my mother, what is the matter, my mother, what is wrong queen of the world? [... ${ }^{90}$

The Virgin Mary as a superior figure of sacred hierarchy but primarily as a mother addresses to Christ who is both her son and God: 
[...] And Christ approached and said: -What is wrong, my mother [...] -My Master, my God and Christ, my Lord $\left[\ldots . .{ }^{91}\right.$

It is worth mentioning that quite often the divine dimension of those two figures is temporarily abandoned and the emphasis is placed on the tender relationship between the mother and the son:

$[\ldots]$-What is wrong, my mother? [... -Oh, my sweet mother $[\ldots]{ }^{92}$

$[\ldots]$-What is wrong, my mother, $[\ldots]$ ? What happened to you, my sweet mother and your head aches? -That, my son, my begotten son $[\ldots] .^{93}$

The liminality of the two basic protagonists, that of Christ and of the Virgin Mary, is framed and supplemented by the liminality that characterizes most elements of this kind of charms. The time in which the affliction occurs is also integrated in the domain of ambiguity/liminality: at the crack of dawn, between day and night, which is neither day nor night, yet it is indeed both. Additionally, the malevolent agents belong to the sphere of sacred and evil. On the one hand, they are taboo categories, while on the other hand, they are sacred agents. ${ }^{94}$ The very cause of the disease should be traced back to the liminal space between admiration and envy, good and evil, which allows for the inclusion of the Apostles and Angels in the group of the agents provoking this kind of affliction.

Although in the charms of the category we examine here the Virgin Mary undertakes the role of the afflicted, her main mediation/liminal role is also sustained. This latter function is enhanced as with her secular, human quality, that of the mother, she takes on the role of the victim and pleads her son, who as both the son and God, undertakes the elimination of one of the most serious and widespread afflictions. As a result of this mediation an effective therapeutic method is delivered to humans by the most powerful figures in the religious hierarchy. This mediation is validated at another level concerning the relation between the text and the contextual frame, the mythical past and the present crucial situation, and, finally, between the sacred narrative figures who suffer and heal, and between the charmer and the sufferer that participate in the ritual..$^{95}$

\section{CONCLUSIONS}

The narrative charms we examined are representative cases of how a superior spiritual figure in the religious hierarchy like the Virgin Mary, may become the 
victim of a serious affliction. The key feature of this sacred figure is the ability to represent a 'betwixt and between' transitional space which is characterized by fluidity: both sacred and secular, human and god, afflicted and healer. This coincidence of opposite and at the same time complementary processes and notions in a single representation characterizes the peculiar unity of her liminality: that which is neither this nor that, and yet both (cf. Turner 1987: 9). This position allows her to move easily between those categories and undertake seemingly contradictory roles in order to achieve the resolution of a crucial moment of human life, irrespectively of being in the role of the afflicted or the healer. Such a creative blurring of boundaries is further enhanced by the ambiguity of almost all the other elements of this kind of charms (Christ as god and human (her son), time and cause of affliction, agents). Furthermore, it allows for the correlation of the text with the contextual frame, the mythical past with the current crucial situation, and finally the connection of the narrative figures and the ones participating in the ritual (the actual healer and the actual afflicted person).

Finally, some further aspects should be underlined, as they provide a basis for further research into this issue. The type of the charm we examined is preserved only via oral tradition. This is not only shown by the vernacular register of the text, but also by the fact that this type has not been recorded in the written tradition of charms, at least as far as the first part of the charms is concerned. ${ }^{96}$ The wide dissemination of this type across a range of areas in Greece, illustrates that it is an independent type that has not derived from modifications, additions or abstractions of parts from other charm types. ${ }^{97}$ The existence or not of a literary prototype is particularly interesting, as it can enlighten the relation between the written and oral tradition of charms as well as provide elements for the historical, cultural route of incantations in south-eastern Europe.

\section{APPENDIX}

Here follow representative examples of the three versions of the charm "the Virgin Mary afflicted" based on the healing treatment. 


\section{TYPE 1:}

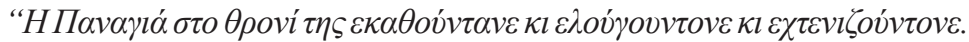

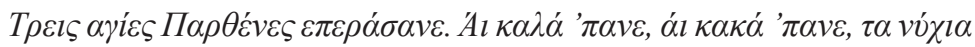

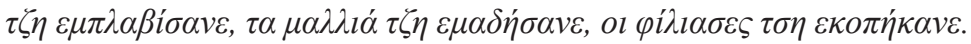

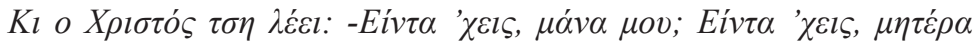

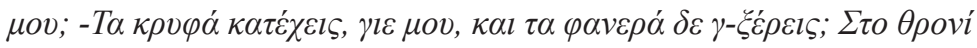

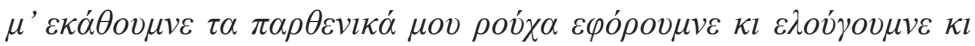

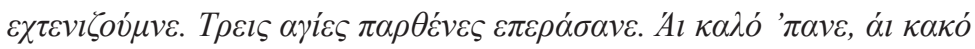

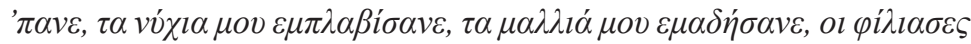

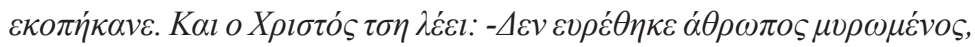

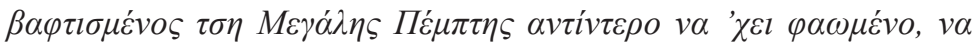

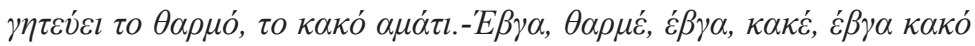

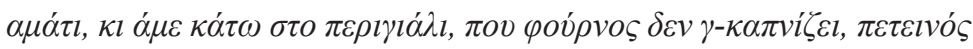
$\delta \varepsilon \gamma-\kappa \rho \alpha \dot{\zeta} \zeta \varepsilon "$.

The Virgin Mary sat on her throne, and washed and combed her hair. Three virgin saints passed by. They uttered good or bad words. Her nails were bruised, her hair fell, her body's joints ached. And Christ says to her: -What is wrong, my mother; What is the matter, my dear mother; [The Virgin Mary answered:] -My son, you know the secrets, don't you know the obvious matters? I was sitting on my throne and wore my virgin clothes. Three virgin saints passed by. They uttered good or bad words. My nails were bruised, my hair fell, my body's joints ached. And Christ says to her: -There hasn't been any man covered with chrism (holy myrrh), who was baptized, who has eaten holy bread of Holy Thursday, to cure the evil eye. -Come out, Tharme (evil eye), come out, malevolent one, come out, evil eye, and go down the shore where stoves

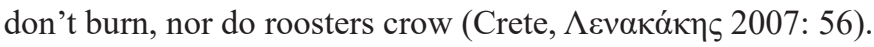

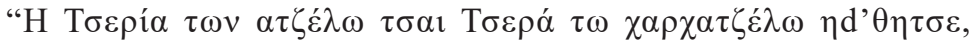

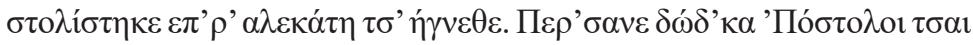
$\tau \eta$

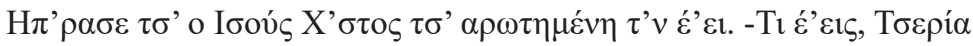

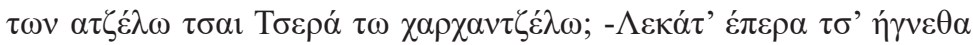

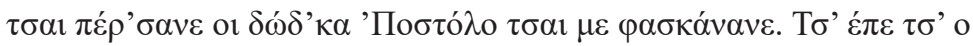

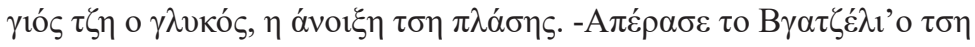




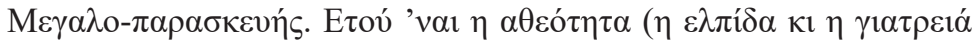
боv)".

The Lady of the Angels and Lady of the Archangels wore her clothes and dressed up took her distaff and started spinning. Twelve Apostles passed by and cast the evil eye on her. Her head ached and her heart broke. Then Christ came and asked her: -What is wrong, Lady of the Angels and Lady of the Archangels? [The Virgin Mary answered:] -I took my distaff and started spinning and twelve Apostles passed by and casted the evil eye on me. And her sweet son, the spring of nature, told her: -Read the gospel of Good Friday. This is your hope and your treatment (Paros, $\Sigma \tau \dot{\varepsilon} \lambda \lambda \alpha \varsigma$ 2004: 466).

\section{TYPE 2:}

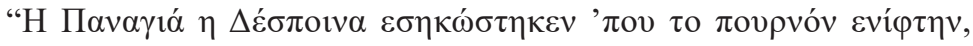

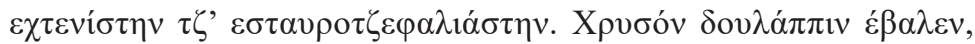

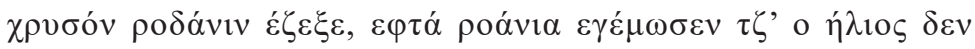

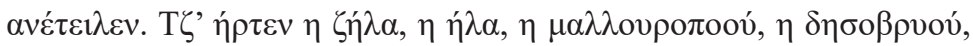

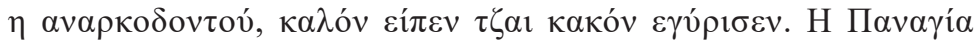

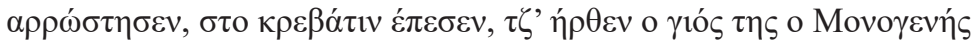

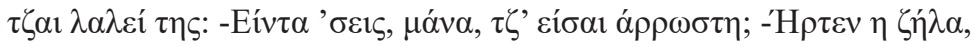

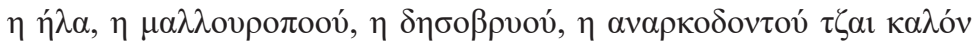

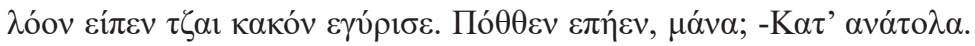

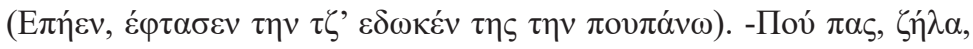

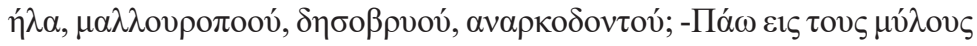

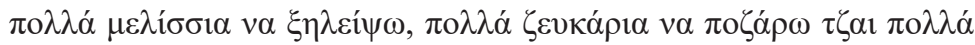

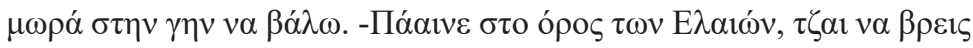

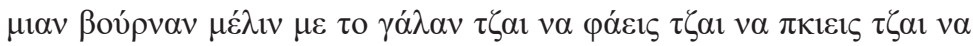

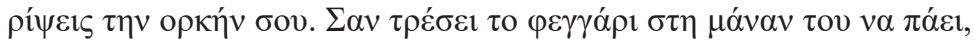

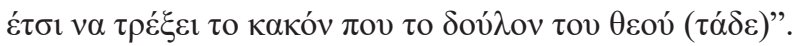

The Virgin Mary, the Mistress, who has been awake up since dawn, washed and combed her hair, put on a headscarf and made the sign of the cross with her fingers, took a golden spindle, turned a golden wheel, filled seven wheels and the sun did not rise. And the jealous one came, who has hairy legs, thick eyebrows, sparse teeth, and she told her good words but evil turned out. The Virgin Mary fell sick, lay down, and her only begotten son came and says to 
her: -What is wrong, mother, and you are sick; [The Virgin Mary answered:] -The jealous one came, who has hairy legs, thick eyebrows, sparse teeth, and told good words but evil turned out.[Jesus Christ said:] -Where did she [the jealous one] go, mother? [The Virgin Mary answered :] -She headed east. (Christ caught her up [and asked her:]).- Where are you heading for? [The jealous one answered:] -I'm going to the mills to destroy many beehives, to separate many couples and bury many babies. [Jesus Christ said:] -Go to the mountain of Olives, find a pond with honey and milk, eat and drink there and cast your rage. As the moon runs to its mother, so shall the evil run away from that servant of God (Cyprus, Iøvós 2007B: 458-459).

\section{TYPE 3:}

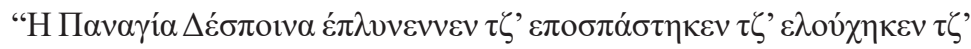

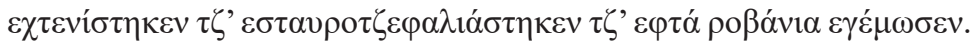

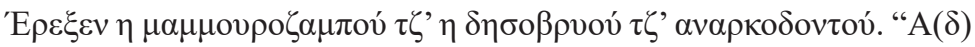

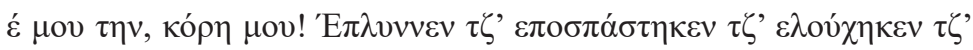

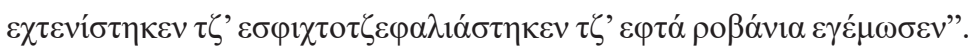

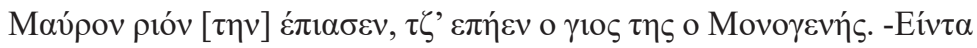

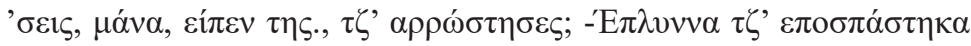

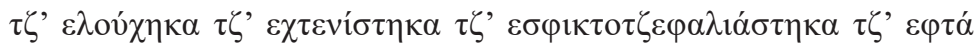

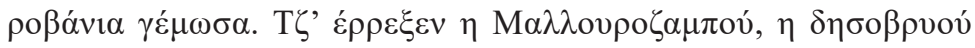

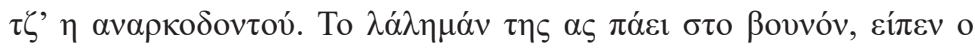

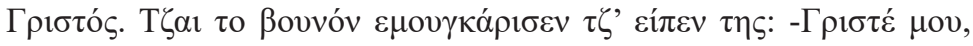

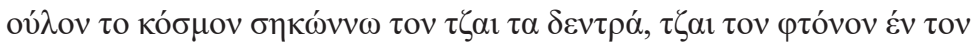

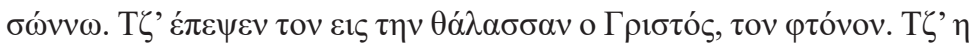

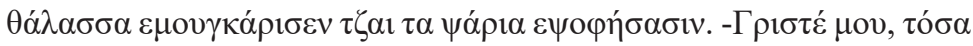

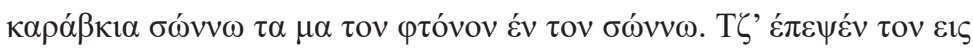

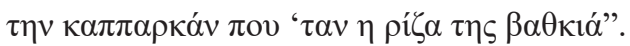

The Virgin Mary washed [her clothes], finished her chores and washed and combed her hair and put on a headscarf and filled the seven wheels of the spindle. And the one with the hairy calves, thick eyebrows and sparse teeth passed by [and said:] -"Look, my daughter! She finished her chores and washed and combed her hair and put on a headscarf and seven wheels of the spin filled". The Virgin Mary suffered from black shivering and her only begotten son 
went. -What is wrong my dear mother, -he told her-, and do you feel sick? I washed, finished my chores and washed and combed my hair and put on a headscarf and filled the seven wheels of the spindle. And the one with the hairy calves, thick eyebrows and sparse teeth passed by. - May her uttering go to the mountain -Christ said-. And the mountain growled and said: -Jesus Christ, I bear the whole world and the trees, except envy. And Christ sent envy to the sea. And the sea growled and the fish died. Jesus Christ, I bear so many ships, but I can't bear envy. So he sent envy to caper whose root was deep (Cyprus,

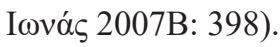

\section{NOTES}

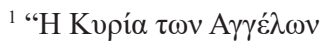

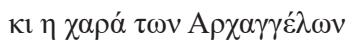

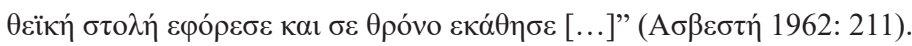

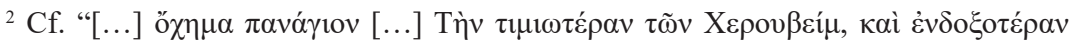

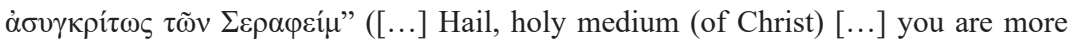
honoured than Cherub and incomparably more glorious than Seraphim) (Salutations to the Virgin Mary). For the typology and symbolism of the figure of Theotokos in hymnography, see Hannick 2004.

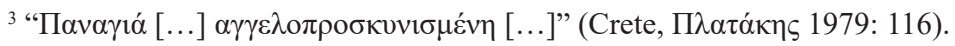

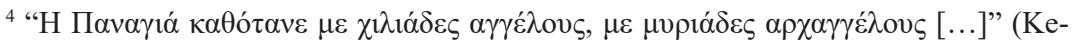

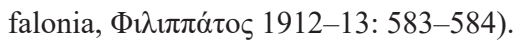

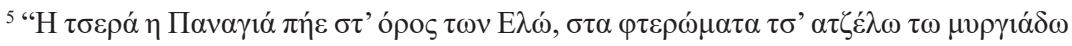

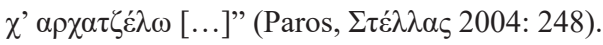

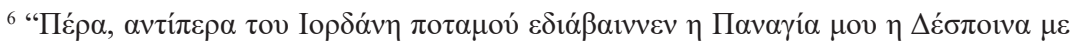

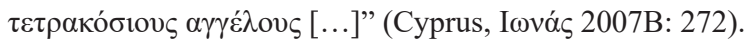

${ }^{7}$ The figure of Panagia is prevalent in all aspects of the daily social and national life of modern Greece and has been recorded in almost all types of oral literature, such

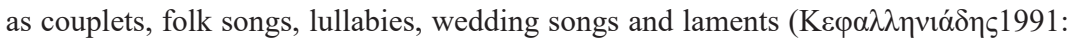
41-74). For the worship of the Virgin Mary in Greek traditional culture see also

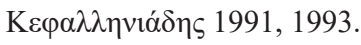

${ }^{8}$ The following references are indicative of the most common names of the Virgin

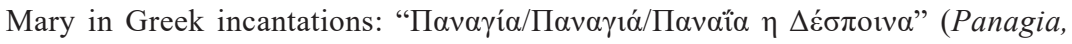

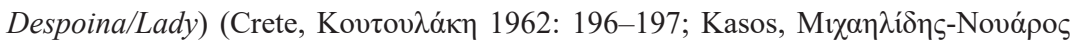




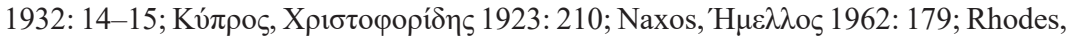

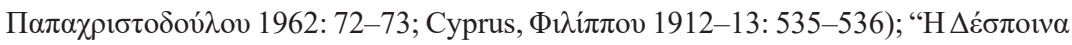

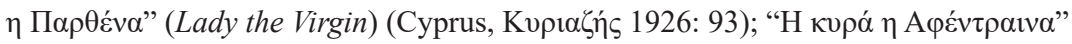

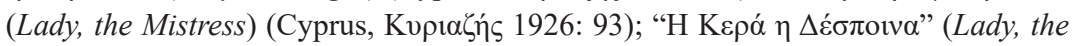

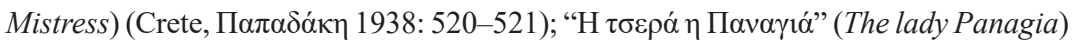

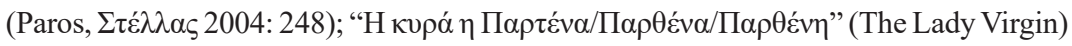

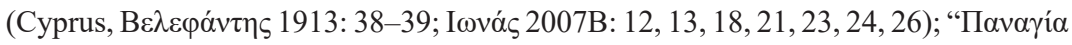

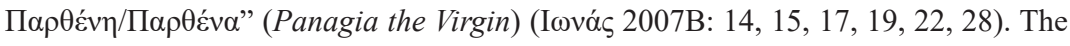

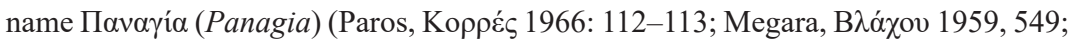

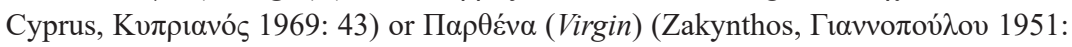
267 ) is rarely cited as such. Finally, it is also worth noting that the name of Panagia, Maria, is rarely found in verbal charms of Orthodox Christianity, and when it does, then hardly ever unaccompanied (Crete, Пó $\gamma \kappa \alpha \lambda$ ऽ 1983: 391), but almost always in close correlation with one of her acknowledged names or titles: "M $\alpha \rho i \alpha(\kappa \alpha 1) \pi \alpha \rho \theta \varepsilon \dot{v} \eta /$

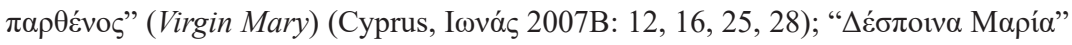
(Despoina Maria) (Crete, Фраүка́кı 1949: 58).

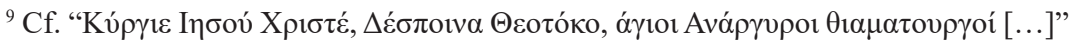
(Lord Jesus Christ, Lady Theotokos, Ss. Anargyroi, the miraculous [...]) (Against evil

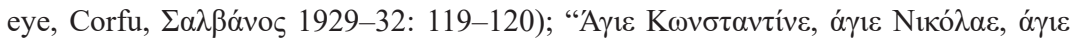

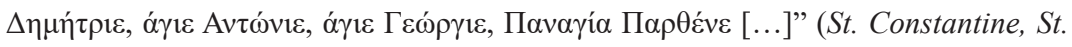
Nicholas, St. Demetrius, St. Antonius, St. George, Virgin Mary [...]) (Against anthrax

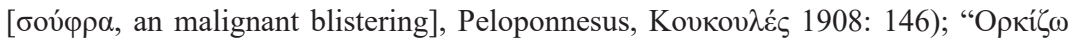

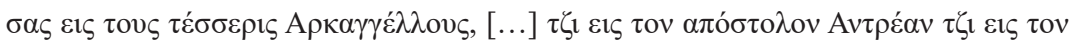

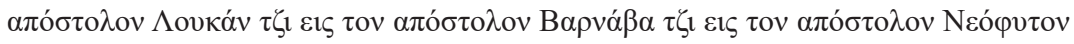

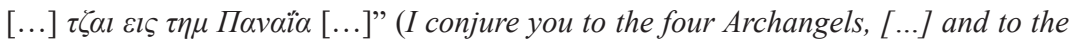
Apostle Andrew and to the Apostle Loukas and to the Apostle Barnavas and to the Apostle

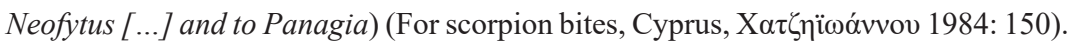
${ }^{10}$ It is also worth mentioned that in oral charms, the first (In the name of the Father) and the last part (and the Holy Spirit) of the above-mentioned sacred formula are frequently omitted, while Christ's and Panagia's names and that of the sufferer are consistently

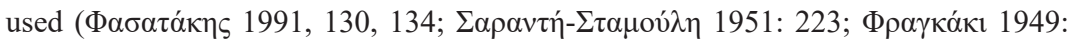
56). The name of St. Panteleimon also is in some cases intervening as the healer saint

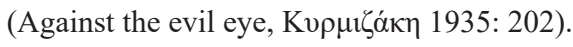

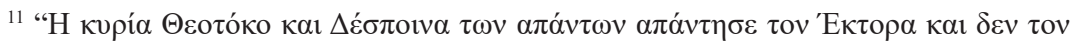

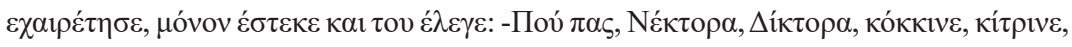
$\alpha \delta \varepsilon \lambda \varphi \varepsilon ́$

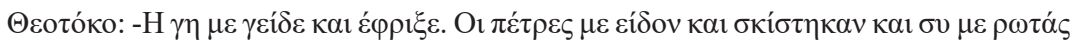

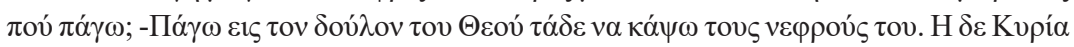




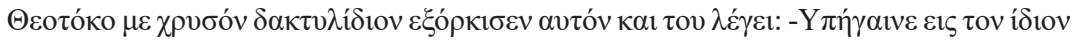

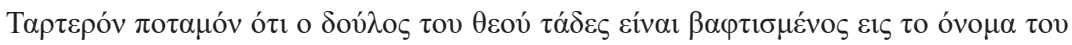

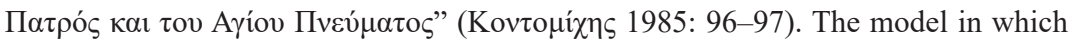
the Virgin Mary performs an exorcism is prevalent in charms for treating jaundice, a disease that infects mainly small children. For similar charms, see I $\omega v \alpha$ c $2007 \mathrm{~B}: 270$,

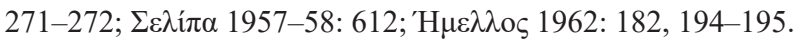

${ }^{12}$ The Virgin Mary's healing intervention upon summoning appears frequently in charms against scorpion's bites. In Ionas' compilation, there are thirteen charms of this type

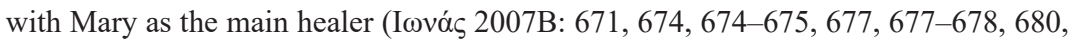

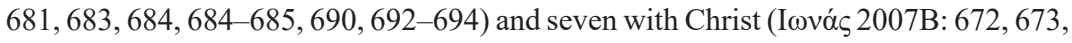
673-674, 679, 687, 688, 690).

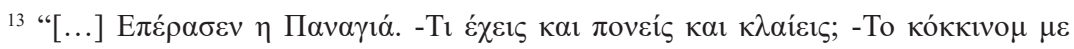

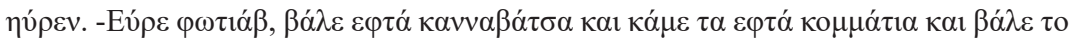

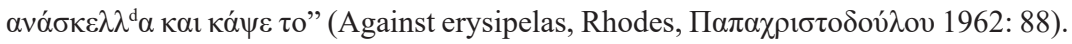

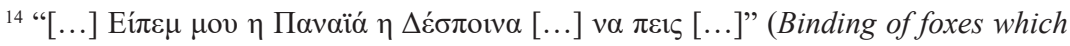

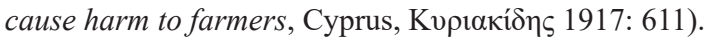

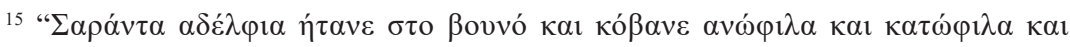

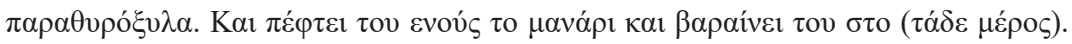

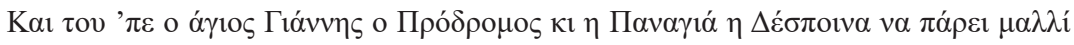

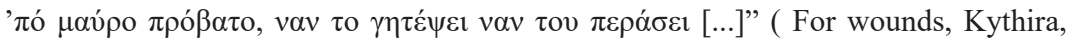

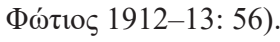

${ }^{16} \mathrm{Cf}$. also note 9 .

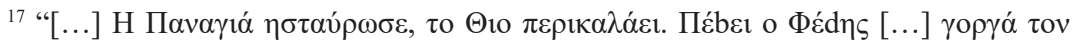

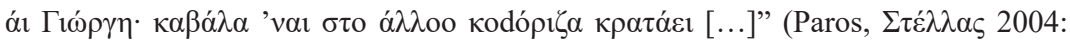
248-249). A similar intervention is documented in a charm for treating wounds and injuries (Crete, Фраүко́кı 1978: 191).

${ }^{18}$ These are the charms against the evil eye which are structured upon the model of the Virgin Mary's encounter with the $\Phi \tau \alpha \rho \mu o ́$ (= wicked eye, personification of the afflic-

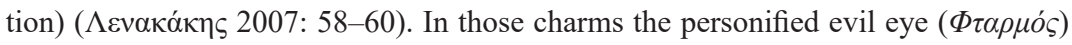
is in process and its malevolent intended action is interrupted by the Virgin Mary's intervention.

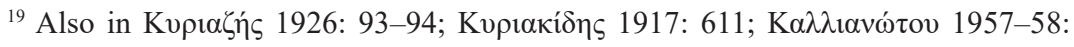

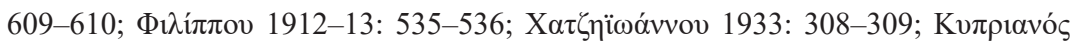

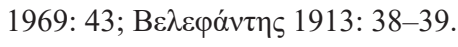

${ }^{20}$ The examination of this issue is based on a collection of 4000 charms from my personal archive. Undoubtedly, further research could reveal more areas of Greece where this type of charm was performed. 
${ }^{21}$ Occurrence of almost the same pattern is documented in charms for combating fright

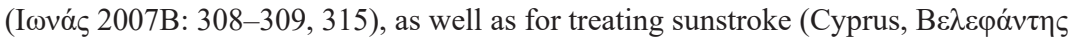
1913: 21). Nonetheless, it is the same charm used against different afflictions.

${ }^{22}$ The case of narrative charms where a sacred figure appears as sufferer is not restricted in the figure of the Virgin Mary. John the Baptist is also documented as a sufferer (For sunstroke, Paros, $\Sigma \tau \varepsilon \dot{\lambda} \lambda \lambda_{\varsigma}$ 2004: 72).

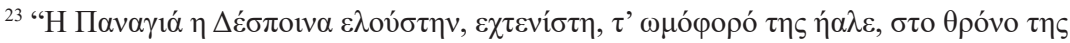

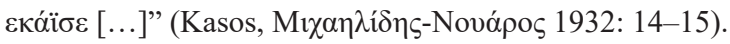

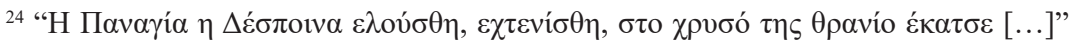

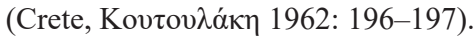

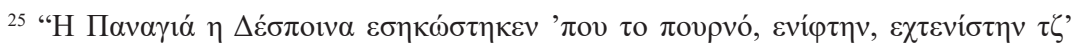

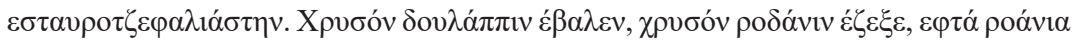

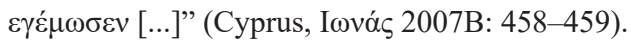

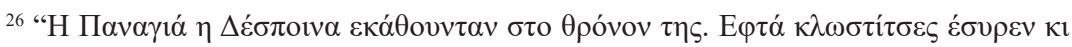

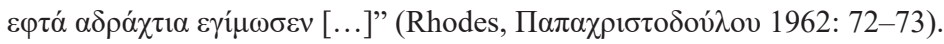

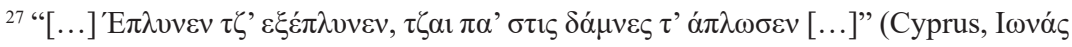
2007B: 361).

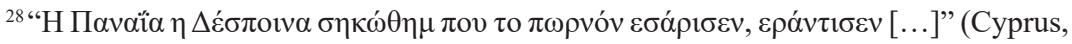

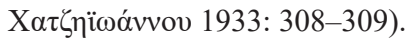

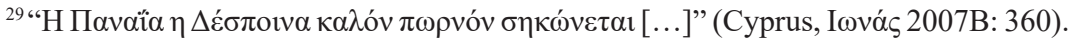

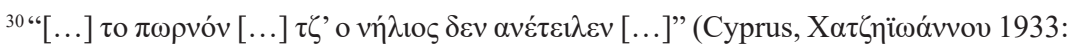
308-309). This temporal reference is found in a vast number of charms, see I $\omega v \alpha$ s

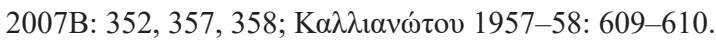

${ }^{31}$ It should not be assumed, however, that the reference to the cave of Christ's birth belongs to the initial core of this type of charms but has been influenced by a text wide-

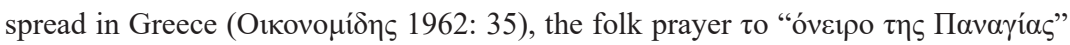

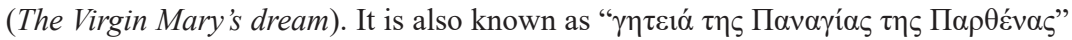

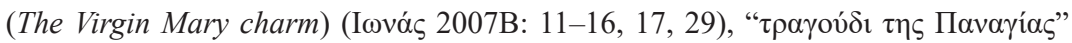

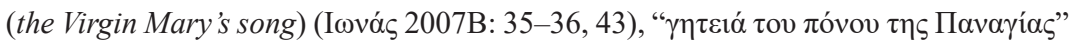

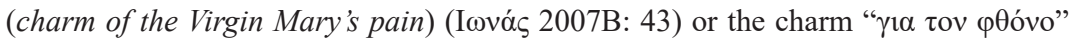

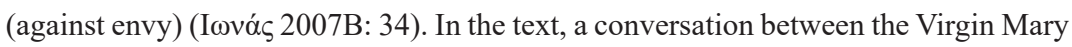
and the newborn Christ is presented. In the dialogue Christ asks his mother the reason for her sadness and she explains that she is sad because she saw a dream related to the betrayal of Christ by one of his Apostles as well as to her son's imminent torment

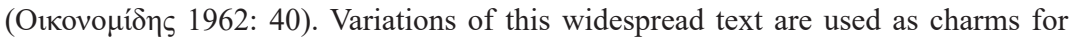

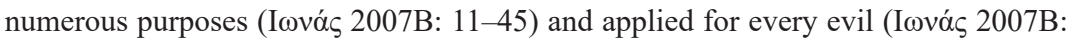
41). Variants of this text are recorded in the wider area of south-eastern Europe, see 


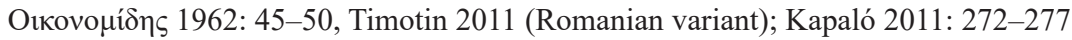
(Gagauz variant). This folk prayer has a different structure from the type we examine in this article. However, the characteristic beginning in the first verse of the folk prayer "Our Virgin Lady", is synonymous with one characteristic of the charms we examine here "Virgin Mary, my Mistress", allowing for transferring parts from one to the other.

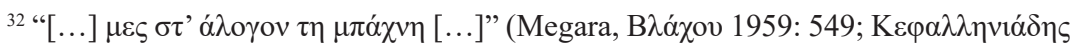
1997: 79).

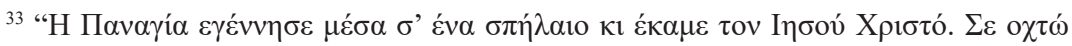

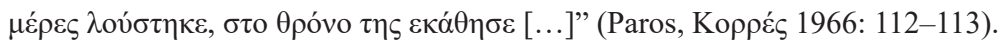

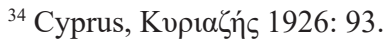

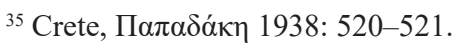

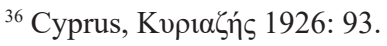

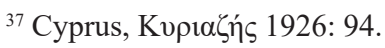

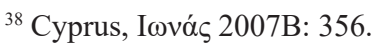

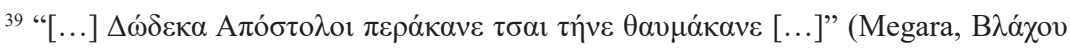
1959: 549).

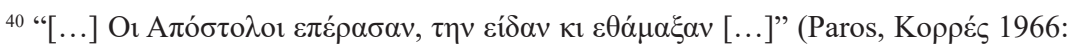
112-113).

41 “[...] O1 $\delta \omega ́ \delta \varepsilon \kappa \alpha$ А

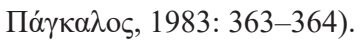

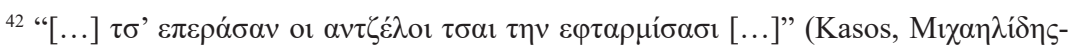
Novápos 1932: 14-15).

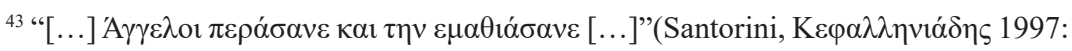
76).

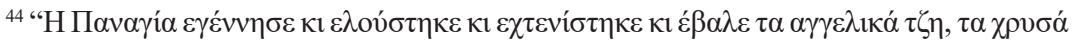

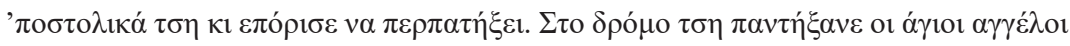

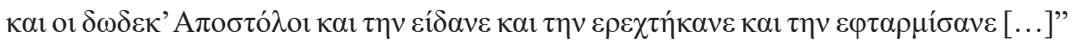

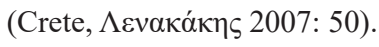

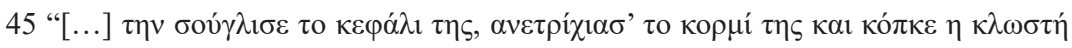

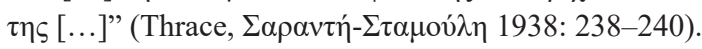

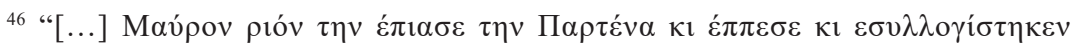

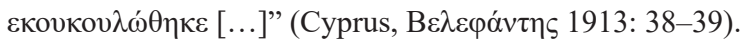

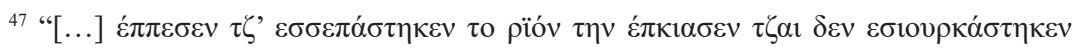

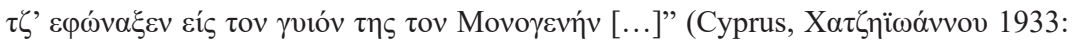
308-309). 


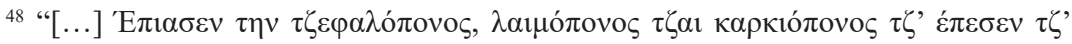

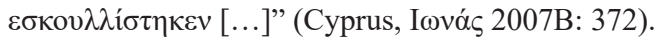

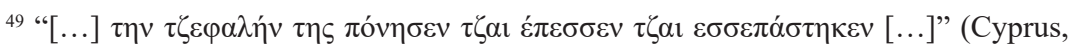

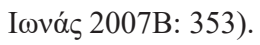

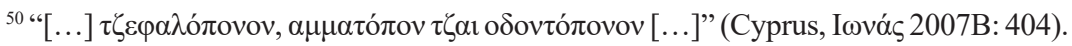

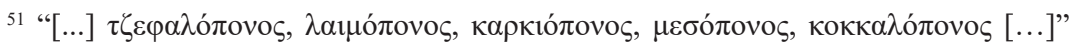

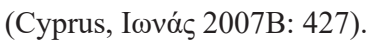

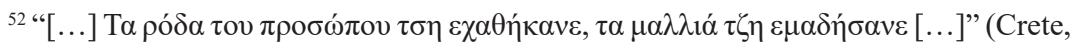

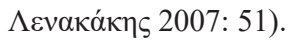

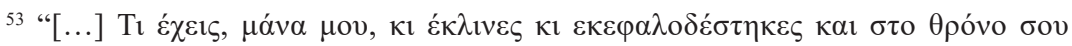

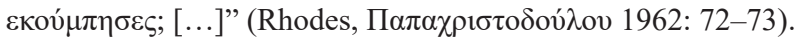

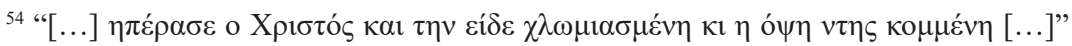

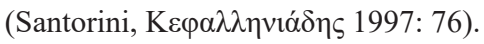

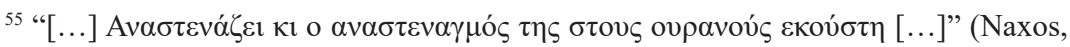

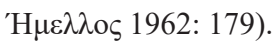

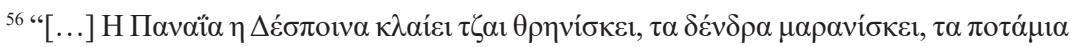

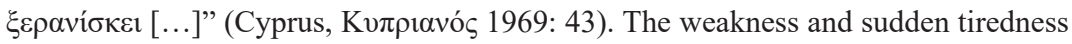
which are regarded as characteristic symptoms of the evil eye are expressed with a

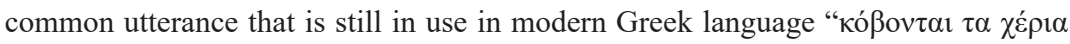

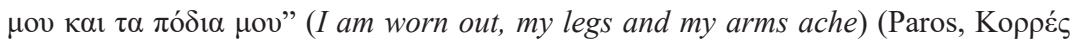
1966: 112-113).

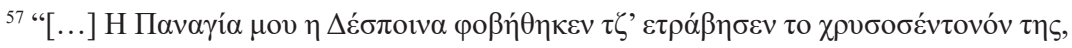

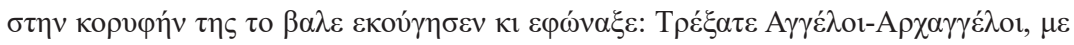

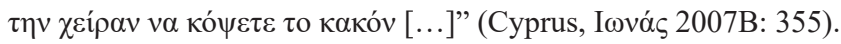

${ }^{58}$ It is worth mentioning that Christ remains the main therapeutic figure even in charms in which the time of action in the narration is set around his birth. In these cases healing

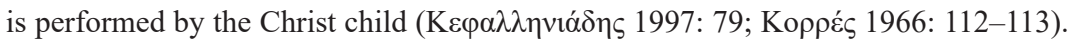
It should not be assumed that these cases are included in the initial type of the incantation, on the contrary, they derive from a text widespread in Greece, the Dream of the Virgin Mary, in which a youthful Christ converses with the Virgin Mary about her dream. See also note 31 .

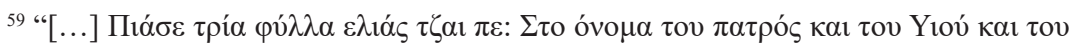

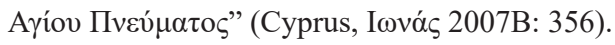

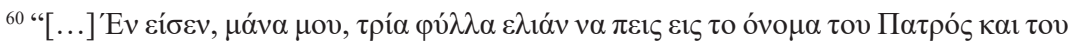

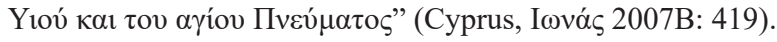




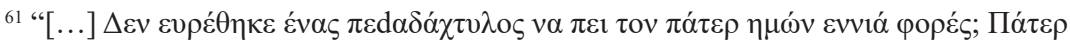

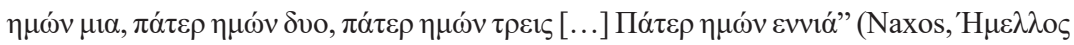
1962: 179).

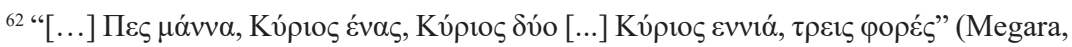

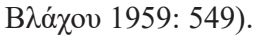

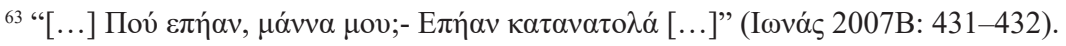

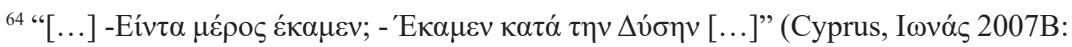
361).

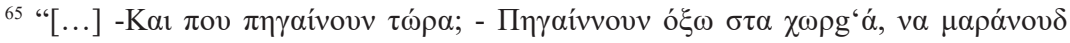

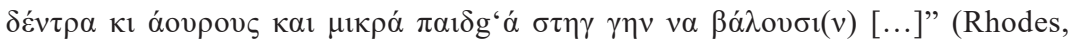

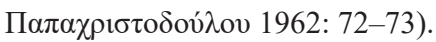

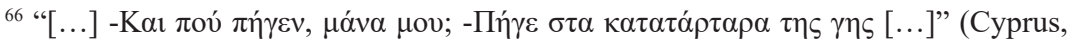

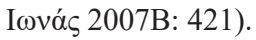

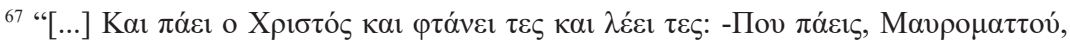

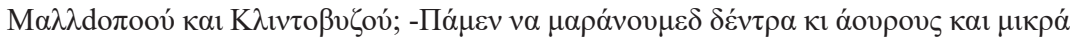

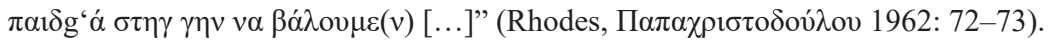

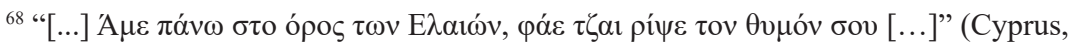
I $\omega$ vós 2007B: 361).

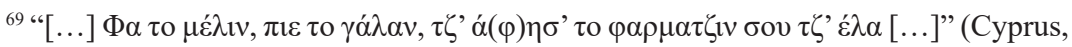

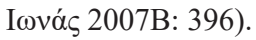

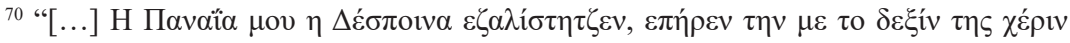

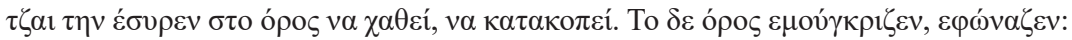

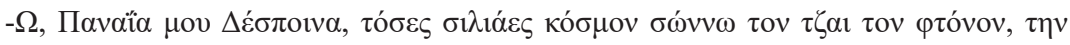

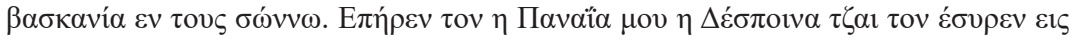

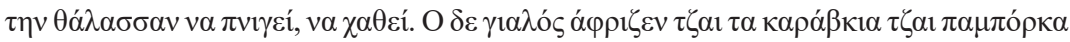

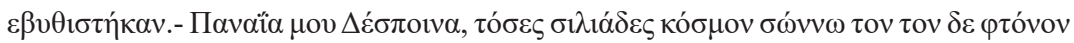

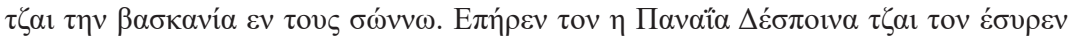

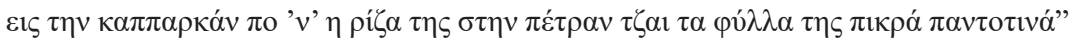

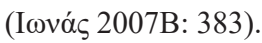

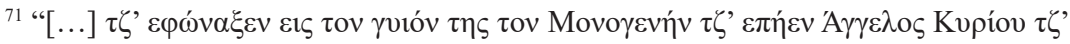

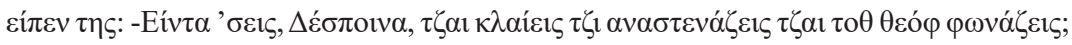

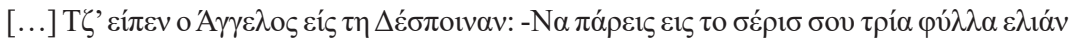

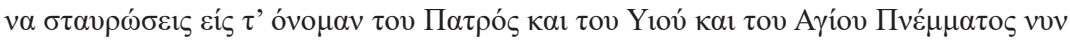

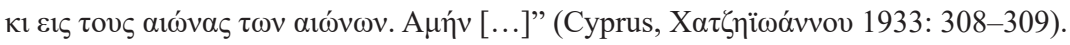

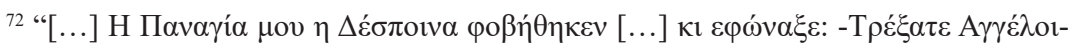

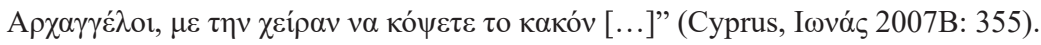


${ }^{73}$ The significance of this affliction is, on the one hand, evident in the fact that the majority of the recorded Modern Greek charms concern the healing of the evil eye, and, on the other hand, in the fact that relevant modified rituals have survived and they are even performed nowadays in rural as well as in urban areas. Moreover, its danger is shown by the popular belief that the evil eye apart from humans can also affect animals, plants and objects, and also by the conviction that it can even lead to death (Фраүко́к1 1978: 68).

${ }^{74}$ One of the most impressive descriptions regarding the Virgin Mary's physical appearance is recorded in the following charm from the area of eastern Thrace: [...] The Virgin Mary was washing her hair in a meadow. In a golden bowl washing her hair, water was poured from a golden cup, she was combing her hair with a golden comb wore her hair in a golden braid, sat on a golden chair, took a golden distaff, she had a golden spindle and made a golden thread. Three sisters passed by and casted the evil eye on her. She suffered from a severe headache, chilled all over her body and her

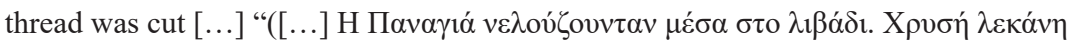

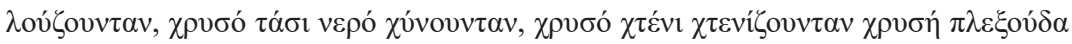

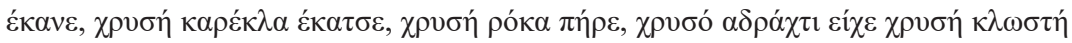

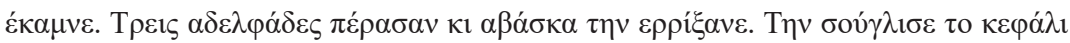

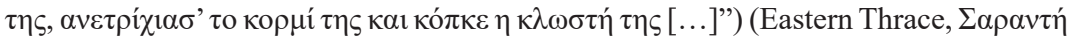

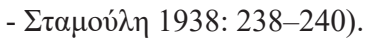

${ }^{75} \mathrm{Cf}$. also "Like many other peoples throughout history, the Byzantines believed that it was pregnant mothers and new-born children who were the most susceptible to the workings of the envious eye because of the risks and dangers arising from pregnancy and childbirth. A whole series of apotropaic practices relating to babies and children indicates how widespread this belief was [...]" (Foscolou 2005: 255).

${ }^{76} \mathrm{Cf}$. also the depiction of the Virgin with the Christ child at her breast in Greek icons (Galaktotrophousa, Virgo lactans). For this type of representation in iconography, see Foscolou 2005: 251 (extended bibliography ibid., note 3); Bolman 2004, 2005:13-22;

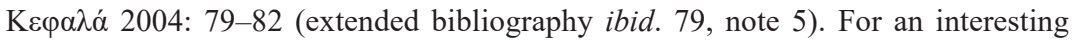
comparative approach to the Virgin Mary and Isis based on the lactans iconography see Higgins 2012; Thomas and Norman 2005.

${ }^{77}$ See also notes 31 and 58.

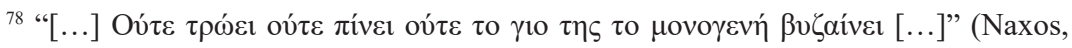

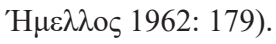

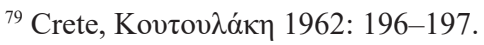

${ }^{80}$ For the female demon Gellou/Gyloy in Modern Greek charm and legends, see Passalis 2015: 115-127. 
${ }^{81}$ About the categories witchcraft-sorcery and the problem of distinction between them, see Yalman 1972: 523. Cf. the distinction external-internal and uncontrolled-controlled power mentioned by Douglas (1966: 98-99).

82 These are mainly groups of taboo people, with special deviations and malformations

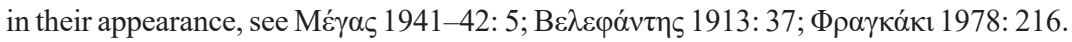

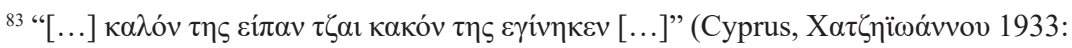
308-309).

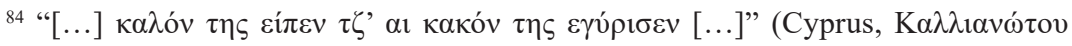
1957-58: 609-610).

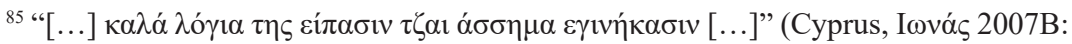
356).

${ }^{86}$ The term liminal derives from the Latin word limen which means "threshold", and which was used to declare and represent the intermediate stage of rites of passage by van Gennep ([1908]1960), the threshold of the transition from one category (place, time, social status) to another, in which one leaves behind his old identity and lies in the intermediate stage of ambiguity. It is a particularly powerful field (locus of power). This stage, was used by anthropologists, like Douglas (1966: 1975) and Leach (1964: 23-63) as an intermediate/liminal point between the two categories A and B, for the investigations of classification mechanisms (Werbner 2001: 138-140).

${ }^{87}$ It is characteristic that Mary Douglas uses the term anomaly to describe the capacity of this liminal stage, as it cannot be classified (1966: 37-38).

88 The Virgin Mary's power to mediate has also been documented in many songs

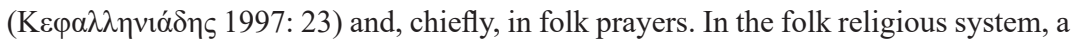
widespread apocalyptic text entitled "The Apocalypse of the Theotokos" clearly demonstrates the mediating role of the Virgin Mary. In this text the Virgin Mary is at the Mount of Olives and pleads the Archangel Michael to reveal the sinners in Hades (the underworld equal to hell). Accompanied by the Archangel Michael, the Virgin Mary visits hell where she sees thousands of sinners being tortured. She pleads for God's mercy for those sinners. God refuses claiming that they have fallen by unforgivable sins. Then the Virgin Mary gathers all archangels, John the Baptist, the twelve Apostles, the prophets and martyrs to support her claim. God responds to her call and agrees to grant them days of rest from Easter until All Saints' Day. For the content and the variants and the dissemination of this text, see Подíms 1874: 373-389; Pernot 1900;

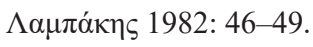

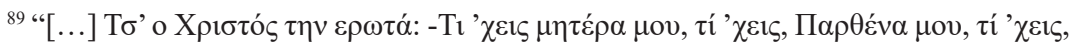

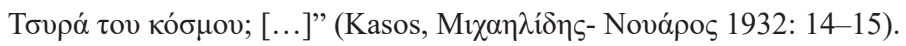




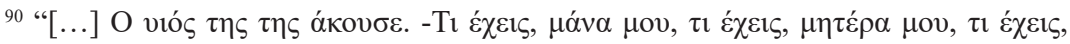

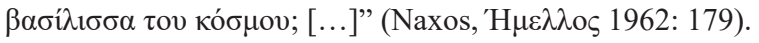

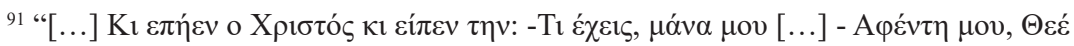

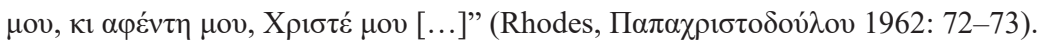

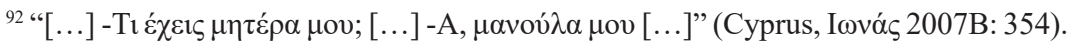

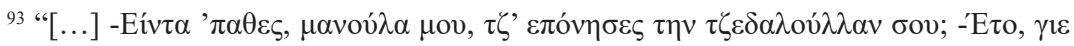

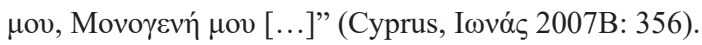

${ }^{94}$ According to Turner, this liminal stage which enhances the appearance of structures "Living through" can be defined "fructile chaos, fertile nothingness, a store house of possibilities, not by any means a random assemblage but a striving after new forms and structure, gestation process, a fetation of modes appropriate to and anticipating postliminal existence" (Turner 1991: 11).

${ }^{95}$ For this kind of mediation between text and contextual

${ }^{96}$ The second part of all narrative charms of all types with spiritual figures on leading roles, that concerns healing, has a rising rate of mobility and easily moves among charms of various types. Consequently, elements of the second part from the type of charms we examine here can be traced in other types. For example, the second type which is based on an encounter between a sacred figure and the personified cause of evil constitutes an independent type of charm against the evil eye with Christ playing a crucial role. The expulsion of a malevolent figure to the Mountain of Olives is a common pattern in the type of charms against bites by poisonous reptiles. Nonetheless, we cannot draw secure conclusions about one type of charms based solely on their second part.

${ }^{97}$ A similar characteristic introduction is found in charms against the evil eye in Crete:

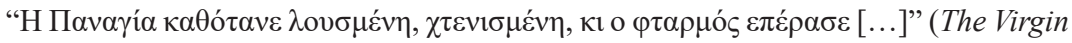
Mary sat on her throne, having her hair washed and combed and the evil eye passed

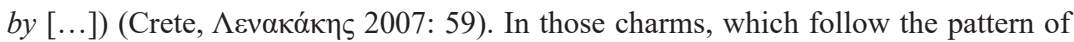
an encounter between a sacred figure and evil in action, the Virgin Mary encounters

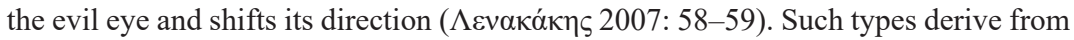
a fusion of charms of the type we examine with the charms that present Christ as the main figure, who encounters the malevolent agents and alters their direction. The pattern of the encounter of certain figures (mother and son) who work in the vineyard with women who have certain malformed external characteristics is found in literary charms (written in archaic language) that are used to protect the vineyard against the evil eye

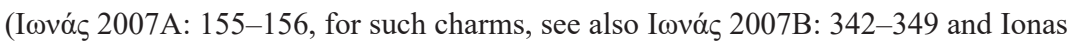
2005). The typical introduction tp those charms though is totally different (Mother and son planted a vineyard in the desert) and the second part concerning treatment follows a totally different pattern. 


\section{REFERENCES}

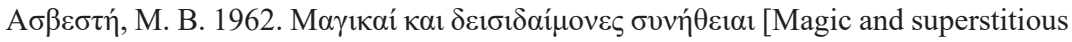

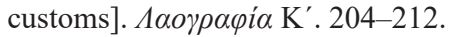

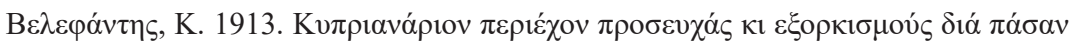

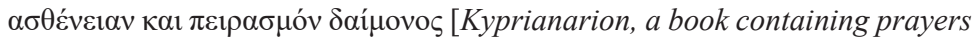
and exorcisms for each disease and demonic temptation]. Ev $\Lambda \varepsilon v \kappa \omega \sigma i ́ \alpha$ Kú $\pi \rho \circ$ :

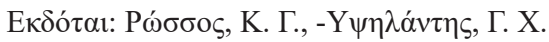

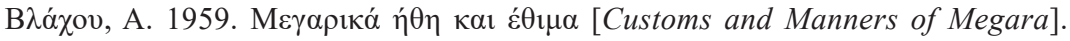

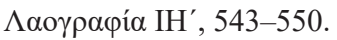

Bolman, E. S. 2004. The Coptic Galaktotrophousa Revisited, in M. Immerzeel and J. Van der Vliet (eds.), Coptic Studies on the Threshold of a New Millennium. Proceedings of the Seventh International Congress of Coptic Studies. Leiden, August 27 - September 2, 2000. Louvain: Peeters, pp. 1173-1184.

Bolman, E. S. 2005. The enigmatic Coptic Galaktotrophousa and the cult of the Virgin Mary in Egypt, in M. Vassilaki (ed.), Images of the Mother of God. Perceptions of the Theotokos in Byzantium. Aldershot: Ashgate, pp. 13-22.

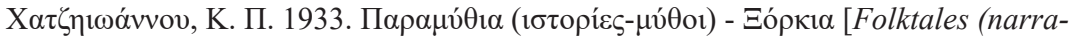

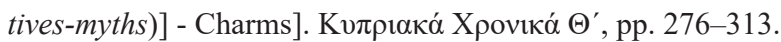

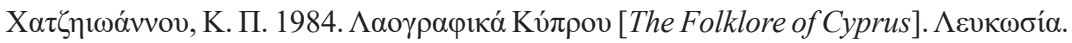

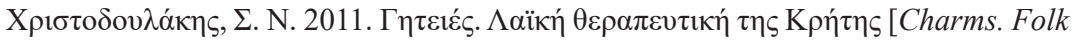

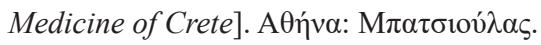

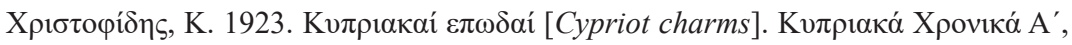
208-210.

Douglas, M. 1966. Purity and Danger: An Analysis of Concepts of Pollution and Taboo. London: Routledge and Kegan Paul.

1975. Implicit Meaning. London: Routledge \& Kegan Paul.

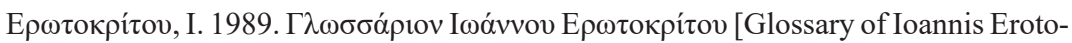

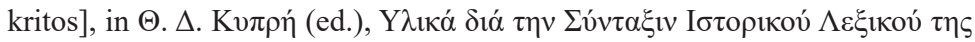

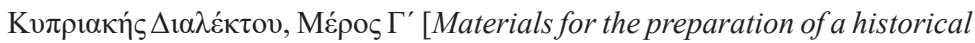

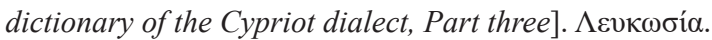

Evans-Pritchard, E. E. 1977. Witchcraft, Oracles and Magic among the Azande. Oxford: Oxford University Press.

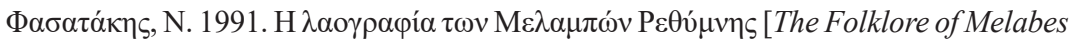

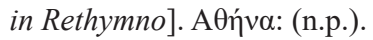

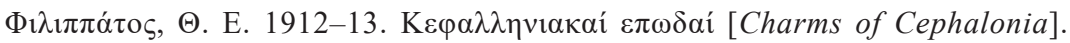
$\Lambda \alpha о \gamma \rho \alpha \operatorname{í}_{\alpha} \Delta^{\prime}, 537-539$.

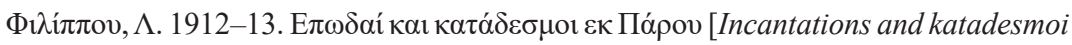

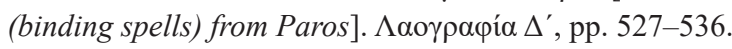




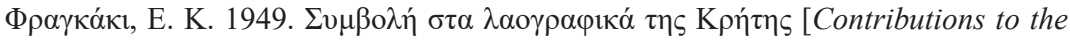
Folklore of Crete]. A $\theta$ íva.

Foskolou, V. 2005. The Virgin, the Christ-child and the evil eye, in M. Vassilaki (ed.), Images of the Mother of God. Perceptions of the Theotokos in Byzantium. Aldershot: Ashgate, pp. 251-262.

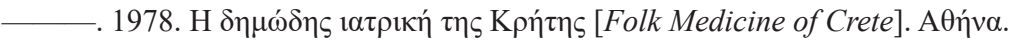

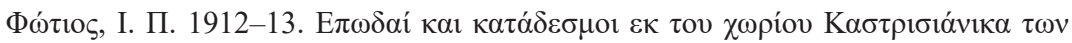

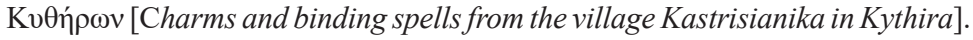
$\Lambda \alpha о \gamma \rho \alpha \varphi \alpha_{\alpha} \Delta^{\prime}$, pp. 53-59.

(van) Gennep, A. [1908] 1960. The Rites of Passage. Transl. by M. B. Vizedom- G.L. Caffee. Chicago: The University of Chicago Press.

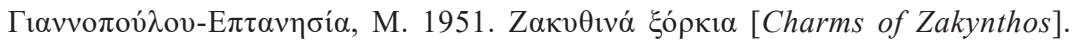

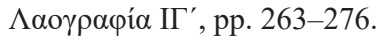

Hannick, C. 2004. The Theotokos in Byzantine hymnography: typology and allegory, in M. Vassilaki (ed.), Images of the Mother of God. Perceptions of the Theotokos in Byzantium. Aldershot: Ashgate, pp. 69-76.

Higgins, S. 2012. Divine Mothers: The Influence of Isis on the Virgin Mary in Egyptian Lactans-Iconography. Journal of the Canadian Society for Coptic Studies 3-4: 71-90.

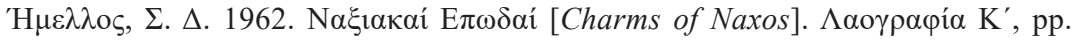
176-195.

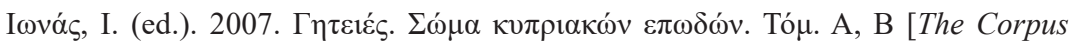

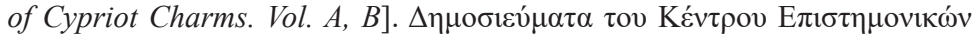

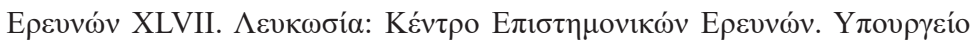

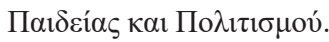

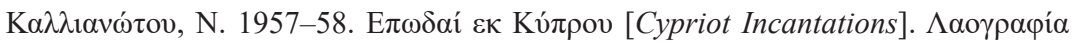
IZ', pp. 609-611.

Kapaló, J. 2011. Text, Context and Performance. Gagauz Folk Religion in Discourse and Practice. Brill: Leiden Boston.

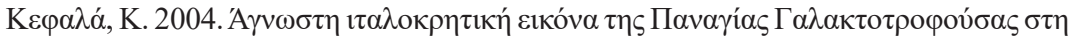

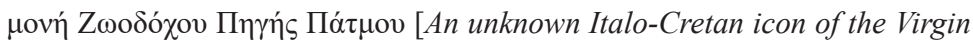
Galaktotrofousa in The Zoodochos Pigi Monastery in Patmos]. $\Delta \varepsilon \lambda \tau i$ ov $\tau \eta \varsigma$

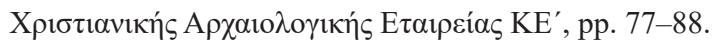

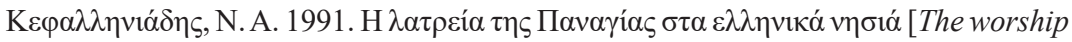

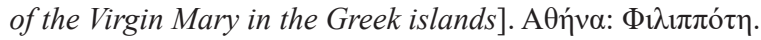

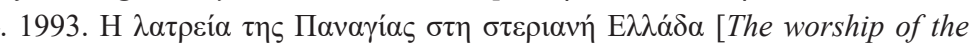

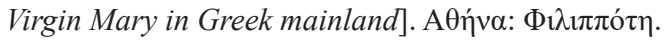




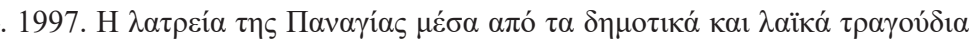
[The worship of the Virgin Mary through the study of demotic (folk) songs].

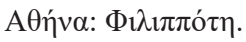

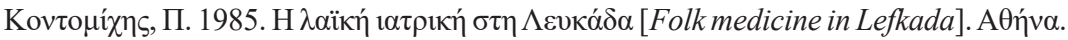

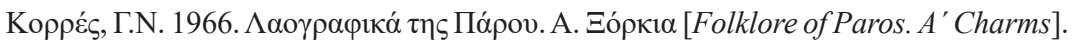

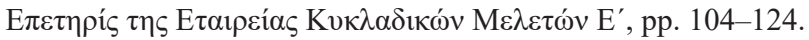

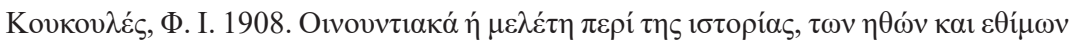

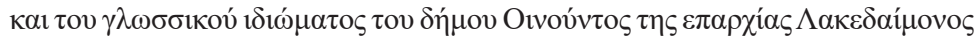
[On Oinountas or Study on the History, Manners and Customs and the Linguistic Idiom of the Municipality of Oinountas in the Prefecture of Lakedaimon]. Xavió.

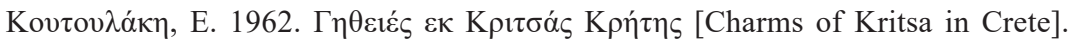

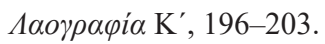

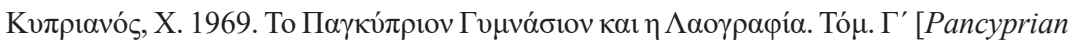

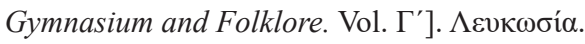

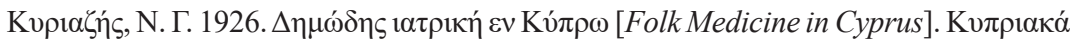

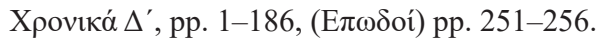

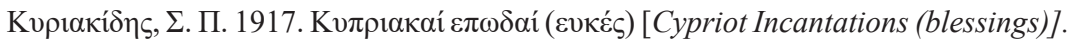

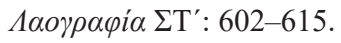

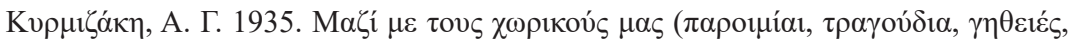
$\left.\pi \alpha \rho \alpha \mu v \theta_{1 \alpha}\right)$ [Together with our villagers (proverbs, songs, charms, folktales].

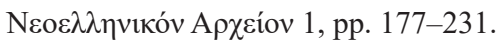

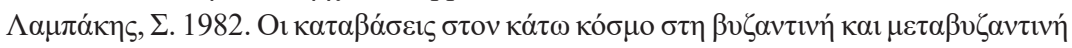

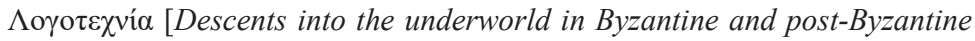
literature]. Doctoral dissertation. A $\theta \dot{v} v \alpha$.

Leach, E. R. 1964. Anthropological Aspect of Language: Animal Categories and Verbal Abuse, in E. H. Lenneberg (ed.), New Direction in Language. Cambridge, Mass.: MIT Press, pp. 23-63.

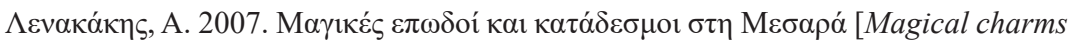

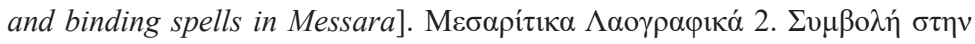

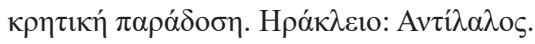

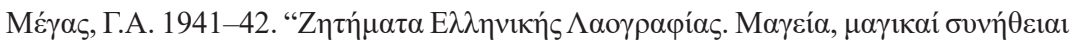

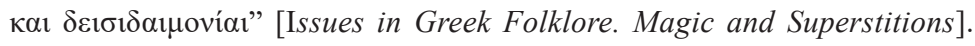

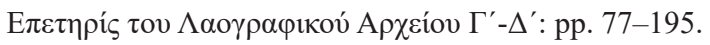

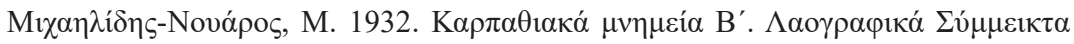

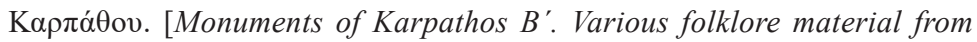
Karpathos]. A $\theta \dot{v} \alpha$.

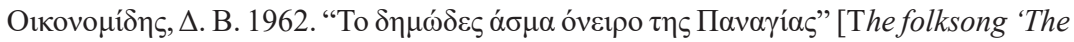

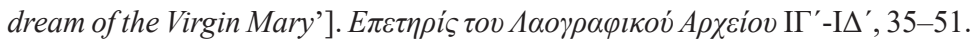




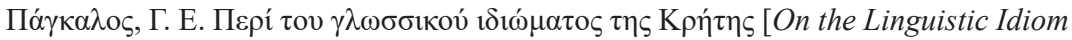

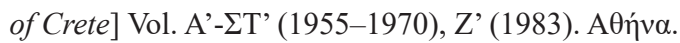

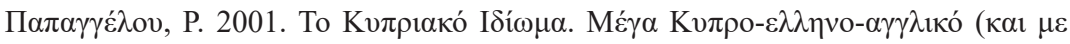

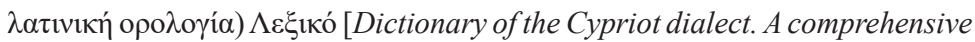

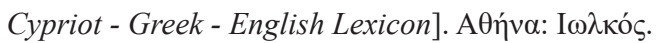

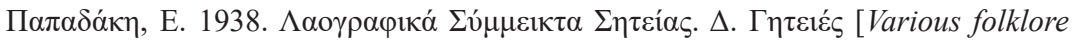

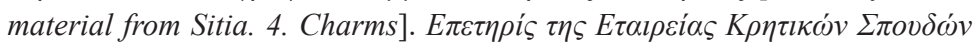
1: 513-529.

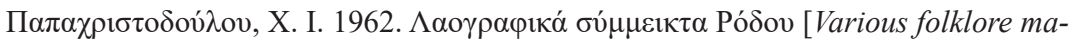

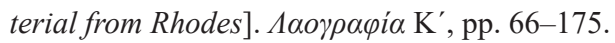

Passalis, H. 2011. Myth and Greek Narrative Charms: Analogy and Fluidity, in Tatyana A. Mikhailova, Jonathan Roper, Andrey L. Toporkov and Dmitry S. Nikolayev (eds.), Oral Charms in Structural and Comparative Light. Moscow: PROBEL, pp. 43-49.

2015. From Written to Oral Tradition. Survival and Transformation of St. Sisinnios Prayer in Oral Greek Charms. Incantatio 4: 111-138.

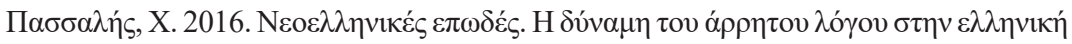
$\lambda \alpha \ddot{\kappa} \eta \dot{~ \pi \alpha \rho \alpha ́ \delta о \sigma \eta ~[M o d e r n ~ G r e e k ~ I n c a n t a t i o n s . ~ T h e ~ p o w e r ~ o f ~ t h e ~ u n t o l d ~ w o r d ~}$

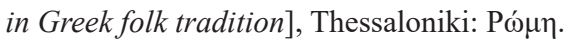

Pernot, H. 1900. Descente de la Vierge aux enfers d'après les mss. grecs de Paris. Revue des études grecques 13: 233-257.

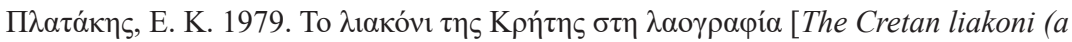

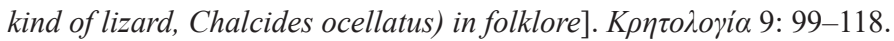

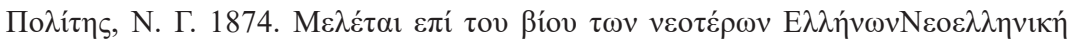
$\mu v \theta 0 \lambda \mathrm{o} \gamma \mathbf{i} \alpha$. Vol. B' [Studies on the life of Modern Greeks. Modern Greek myt-

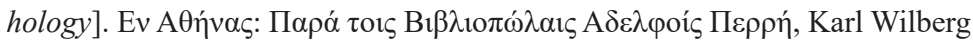

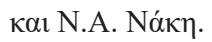

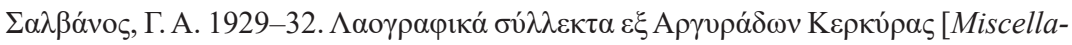

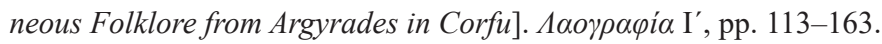

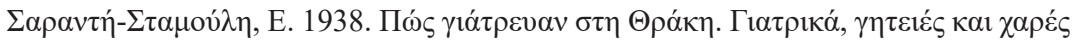
[The way they used healing practices in Thrace. Medicines, Charms, and Joys].

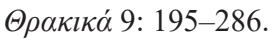

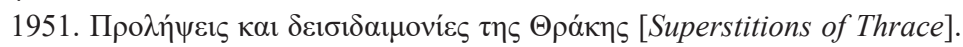

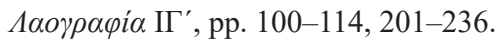

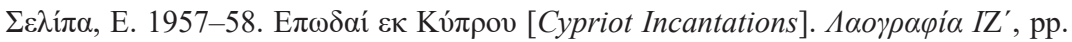
611-613.

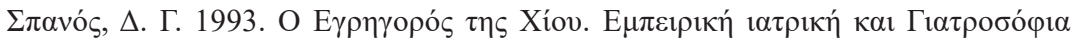
[Egrigoros of Chios. Empirical and Folk Medicine], in X $\alpha \beta$ เó $\rho \alpha-K \alpha \rho \alpha \chi \alpha ́ \lambda$ เov 


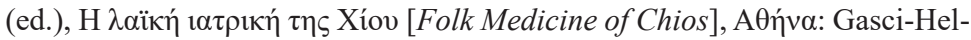
las, pp. 420-431.

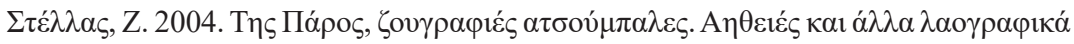
$\kappa \alpha \iota ~ \gamma \lambda \omega \sigma \sigma 1 \kappa \alpha ́$ [Clumsy/Blowsy Paintings of Paros: Charms and other linguistic and folk material]. A $\theta \dot{v} \alpha$.

Thomas F. M. and Norman E. M. 2005. Isis and Mary in early icons, in M. Vassilaki (ed.), Images of the Mother of God. Perceptions of the Theotokos in Byzantium. Aldershot: Ashgate, pp. 3-12.

Timotin, E. 2011. Les apocryphes et leurs moyens de légitimation. Le Rêve de la Vierge dans la tradition roumaine. New Europe College. Ştefan Odobleja Program Yearbook 2010-2011, Bucharest: New Europe College, pp. 211-253.

Turner, V. 1987. Betwixt and Between: The liminal period, in Louise Canus Mahdi, Steven Foster and Meredith Little (eds.), Rites of Passage in Betwixt and Between: patterns of masculine and feminine initiation. Chicago: Open Court Publishing, pp. 3-19.

1991. Are there universals of performance in myth, ritual, and drama?, in Richard Schechner and Willa Appel (eds.), By means of performance. Intercultural Studies of Theatre and Ritual. Cambridge: Cambridge University Press, pp. 8-18.

Yalman, N. 1972. Magic, David, L. Sills (ed.), Encyclopaedia of the Social Sciences. Vol. 10. New York: The Macmillan Company and the Free Press, pp. 521-528.

Werbner, P. 2001. The Limits of Cultural Hybridity: On Ritual Monsters, Poetic Licence and Contested Postcolonial Purifications. The Journal of the Royal Anthropological Institute 7, 133-152.

\section{BIO}

Haralampos Passalis is a teacher of Greek language currently working part-time as guest lecturer at the University of Amsterdam (UvA, Department of Modern Greek Studies) and at the Greek School "Athena” located in Amsterdam. His personal research interests mainly focus on lexicography, teaching Greek as a foreign language and rites and customs in traditional Greek culture. The result of his research on structure and function of Greek oral charms has been

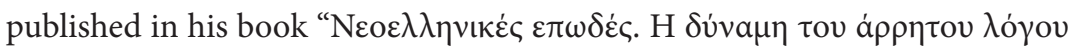

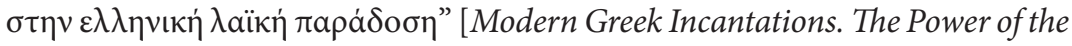

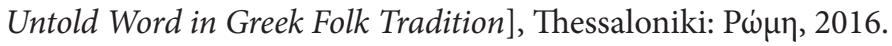

